\title{
Distribution and palaeoecological indicator value of diatoms in Holocene coastal deposits of the southern North Sea (Lower Saxony, Germany)
}

\author{
Frank Watermann, Holger Freund \& Gisela Gerdes ${ }^{*}$
}

Keywords: diatom analysis, Holocene, palaeoenvironment, palaeoecology, North Sea, Germany, sea-level change

Abstract: The development of the North Sea coastal landscapes during the past 8000 years has been strongly influenced by sea-level fluctuations that involved cyclical transgression, stagnation and even regression phases. Transgressive phases are reflected in NW Germany by Holocene coastal deposits consisting mainly of sand, silt and clay, whereas phases of regressive coastal development are indicated by the presence of peat layers. Although the East Friesian barrier islands in their present state are not older than 2000 years, they possess material that is amenable to palaeoecological investigations. Fossil salt marsh and tidal flat horizons provide natural sea-level indicators that record fluctuations of the mean high tide level in the southern North Sea. This paper presents the results of diatom analyses from boreholes in coastal regions and on the East Friesian barrier islands. Diatom assemblages of the clastic units of marine transgression phases are generally characterized by marine pelagic and littoral diatoms. Nevertheless, oligo- and mesohalobous species also occur, predominantly in direct contact with the basal peat layer suggesting that the first marine transgression proceeded slowly. Tidal flat deposits are characterized by poly- and mesohalobous species, whereas

"Anschriften der Verfasser: PD Dr. Holger Freund, Dr. G. Gerdes, Dr. F. Watermann, Institut für Chemie und Biologie des Meeres (ICBM), Meeresstation, Schleusenstr. 1, D-26382 Wilhelmshaven; E-mail: holger.freund@icbm.terra mare.de lagoonal sediments are dominated by littoral brackish and sometimes fragile diatoms indicating low salinity and calm depositional conditions. Intercalated Phragmites fen peat layers show an increase in littoral oligohalobous species reflecting regressive phases of sea level. Salt-marsh deposits on the East Friesian islands, as well as those in contact with the Pleistocene hinterland, mainly contain aerophilous, littoral species. Flooding events and increasing marine influences are documented by higher amounts of pelagic marine diatoms. Dune slack deposits, which only occur on the islands, and deposits in the uppermost salt-marsh areas show a clear dominance of oligohalobous species suggesting that marine influences are restricted in those environments.

[Verbreitung und paläoökologischer Indikatorwert von Diatomeen in holozänen Küstenablagerungen der südlichen Nordsee (Niedersachsen; Deutschland)]

Kurzfassung: Die Entstehung der niedersächsischen Küstenlandschaften ist während der letzten 8000 Jahre eng mit Meeresspiegelfluktuationen verbunden, die Phasen von Meeresspiegelabsenkungen und -anstiegen ebenso umfassen wie Stillstandsphasen. Transgressive Abschnitte zeichnen sich vor allem durch sandige und tonig-schluffige Ablagerungen aus, während Regressionsphasen zum Teil durch Torf gekennzeichnet sind, der sich in Phasen verlangsamten Meeresspiegelanstieges seewärts auf marine Ablagerungen ausbreiten konnte. Auch auf den Ostfriesischen Inseln ergeben sich Möglichkeiten paläoökologischer Untersuchungen, die ungefähr bis in die Zeitenwende zurückreichen. Hier können vor 
allem ältere Salzwiesenhorizonte und Wattschichten genutzt werden, die heute infolge von Strandverschiebungen am seeseitigen Strand einiger Inseln erosiv freigelegt werden. Diese Horizonte bilden natürliche Pegelmarken, an denen zurückliegende Meeresspiegelstände rekonstruiert werden können. In diesem Artikel werden diatomologische Ergebnisse vorgestellt, die an Bohrungen und Profilen der festländischen Küste und Ostfriesischen Inseln erarbeitet wurden. Die Diatomeen-Vergesellschaftungen klastischer Sedimente, die während Transgressionsphasen abgesetzt wurden, sind generell durch pelagische und litorale marine Arten charakterisiert. Im Kontakt zu den Ablagerungen des Basaltorfes treten verstärkt oligo- bis mesohalobe Arten hinzu. Dies legt den Schluss nahe, dass sich dieser erste transgressive Kontakt nicht erosiv, sondern fließend vollzogen hat. Die Wattablagerungen sind vornehmlich durch eine Artenkombination poly- bis mesohalober Arten gekennzeichnet, während lagunäre Sedimente häufiger litorale brackische und schwach verkieselte Arten aufweisen. Dies deutet auf einen geringeren Salzgehalt und ruhige Ablagerungsbedingungen hin. Die eingeschalteten Niedermoortorfe mit Phragmites zeigen einen Anstieg litoraler oligohalober Arten und bezeugen somit den Rückgang der Salinität und mithin eine regressive Phase innerhalb der Meeresspiegel-Entwicklung. Salzwiesenablagerungen sowohl auf den Inseln als auch im Kontakt zum pleistozänen Hinterland werden durch aerophile litorale Spezies charakterisiert, Überflutungsereignisse deuten sich durch stärkere Nachweise pelagischer mariner Diatomeen an. Sowohl Ablagerungen feuchter Dünentäler, die im Untersuchungsgebiet nur auf den Ostfriesischen Inseln auftreten, als auch die am höchsten gelegenen Bereiche der Salzwiese beherbergen eine Vielzahl oligohalober Spezies und unterstreichen auf diese Weise den zurückgehenden marinen Einfluss.

\section{Introduction}

Diatoms are photosynthetic single-celled algae with a $\mathrm{SiO}_{2}$-cell wall that generally fossilizes well. This opaline frustule is composed of two valves which fit together by girdle bands. The taxonomy of diatoms is mainly based on the shape and structure of these siliceous valves. Most of the littoral pennate species are associated with specific substrates that mainly influence the distribution of these species. The following terms are used: epiphytic, growing attached to other plants; epipsammic, growing on sand, and epipelic, growing on mud.

Epiphytic diatoms, mostly associated with macroalgae, are characteristic of permanently submerged low-energy environments such as ditches, ponds, lakes and lagoons (Vos \& DE Wolf 1988). In intertidal areas epipsammic diatoms are usually part of the littoral populations in lagoons (Vos \& DE WOLF 1988), whereas on intertidal mud flats and salt marshes, epipsammic forms are insignificant. Littoral epipelic species are dominant in these environments (ADMIRAAL 1984). However, epipelic diatom assemblages in salt marshes differ from those on mud flats, as salt-marsh species such as Diploneis interrupta are adapted to irregular inundation (DENYs 1994). The coastal zone is not only characterized by littoral, but also by a high abundance of predominantly planktonic pelagic species living in the water column of the North Sea.

The key difficulty in palaeoecological diatom research is to distinguish autochthonous species from transported, allochthonous species. This differentiation is of major importance especially in tidal and estuarine environments (BRockmanN 1940; Simonsen 1962; Zong 1997; Zong \& Horton 1999). In tidal environments such as tidal channels, the allochthonous taphocoenosis occasionally outnumber the autochthonous taphocoenosis (SIMONSEN 1962). If more than $80 \%$ of the total number of diatoms can be qualified as allochthonous, a detailed environmental reconstruction is not possible (Anderson \& Vos 1992).

Diatoms are important palaeoecological indicators as they are very sensitive to changes in environmental conditions. Diatom analysis can be applied to the study of former palae- 
otidal levels (Vos \& DE Wolf 1988; Denys 1994; Freund \& Streif 1999, 2000), sea-level change and related trans- and regressive coastal developments (Stabell 1982; Palmer \& Clague 1986), and the reconstruction of palaeosalinity gradients (SimONSEN 1962; Moore and MCINTIRE 1977; Juggins 1992). Whereas earlier diatom investigations (BROCKMANN 1928, 1940; Grohne 1959; Benda \& Streif 1971) from the NW German coastal area have been limited to qualitative studies, quantitative diatom investigations of Holocene deposits are rare in contrast to the Netherlands (ANDERson \& Vos 1992; Vos \& de Wolf 1994). In this paper, data on the relative abundance of diatoms in sedimentary sequences from NW Germany are used to characterize facies changes caused by sea-level fluctuations.

\section{Quaternary sea-level fluctuations in the southern North Sea}

During the Weichselian last glacial maximum, 22000 to 18000 years BP, the sea level was ca
110-130 m lower than today and so many parts of the North Sea were dry land (Jelgersma 1979; Cameron et al. 1987; Long et al. 1988; Flemming \& Davis 1994). Subsequently, sea level began to rise during the course of Holocene climatic amelioration. At 9000 years BP the northern limits of the Doggerbank were reached (ZAGWIJN 1986). At this time freshwater conditions still prevailed in the southern part of the North Sea basin, as documented by pollen analyses (BeHre et al. 1985). The subsequent sea-level rise triggered the accumulation of coastal sediments in NW Germany (STREIF 1990; Flemming \& Davis 1994). Between 8600 and $7100 \mathrm{BP}$ sea-level continued to rise at a rate of about $2 \mathrm{~m}$ per 100 years (STREIF 1990), starting from $45 \mathrm{~m} \mathrm{NN}$ and reaching 15 $\mathrm{m} \mathrm{NN}$ in the latter phase of this period $(\mathrm{NN}=$ German zero datum; - a.s.l.). The pre-existing Pleistocene landscape was gradually inundated and covered with marine deposits, starting with the low-lying valley systems (Vos \& DE Wolf 1993; Flemming \& Davis 1994; Ludwig et al. 1979). This steep rise probably lasted until 6500 BP (Menke 1976). However, the

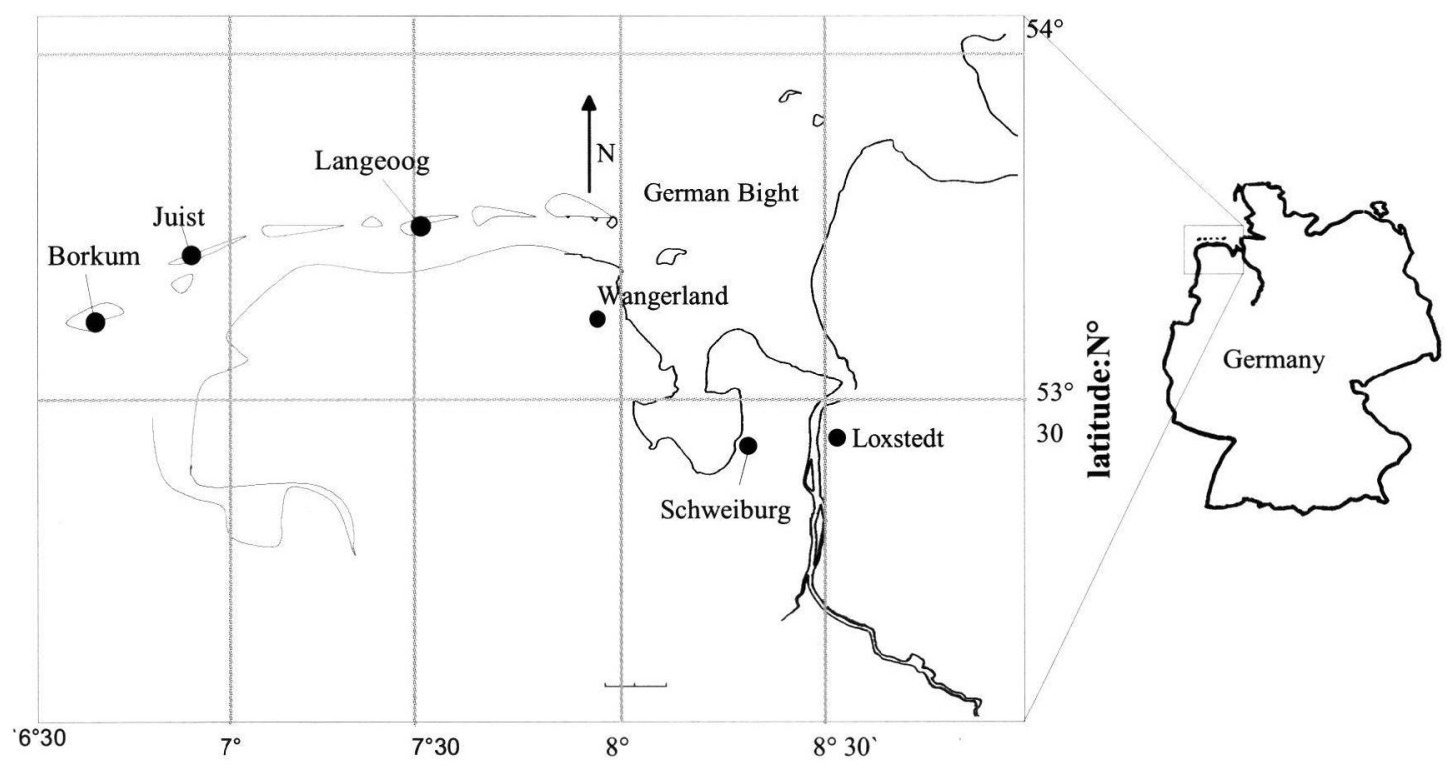

longitude: $\mathbf{E}^{\circ}$

Fig. 1: Map of the study area and the location of drill sites in the southern North Sea region. 
Holocene transgression was not continuous but interrupted by distinct cycles of marine stagnation and even regression phases of sea level. This is evident from the presence of peat layers intercalated in the otherwise clastic Holocene coastal deposits. Due to the lack of dateable material, our knowledge of sea-level fluctuations over the last 2000 years is somewhat limited. New evidence documenting distinct sea-level changes during that period is provided by studies of fossil salt-marsh and tidal flat horizons on the East Friesian Islands (Freund \& Streif 1999, 2000). Increasing human activity has greatly influenced the development of the coastal landscape since Medieval times (ca 1000 years $\mathrm{BP})$. The coastline was actively shaped through the building of dikes in the $11^{\text {th }}$ century, culminating in a continuous system of winter dikes during the $13^{\text {th }}$ century. This prevented natural sedimentation in the dike-protected hinterland. As a consequence, clayey coastal sediments be- came compacted due to drainage, and resulted in a higher storm surge level. This led to severe breaches in dike structure and the formation of new tidal bays such as the Jade bay near Wilhelmshaven or the Dollart near Emden. In contrast, the East Friesian Barrier islands retained a more or less natural/semi-natural environment until the construction of dikes commenced in Modern times.

\section{Study sites}

This work is based on the study of six sampling sites in the southern North Sea (Fig. 1, Tab. 1). In the Pleistocene hinterland four cores were extracted using a Livingstone piston corer (Merkt \& Streif 1970). The Loxstedt drill site, located in the funnel-like Pleistocene palaeo-watercourse of the Weser, lies about $20 \mathrm{~km}$ $\mathrm{SW}$ of Bremerhaven close to the river Weser

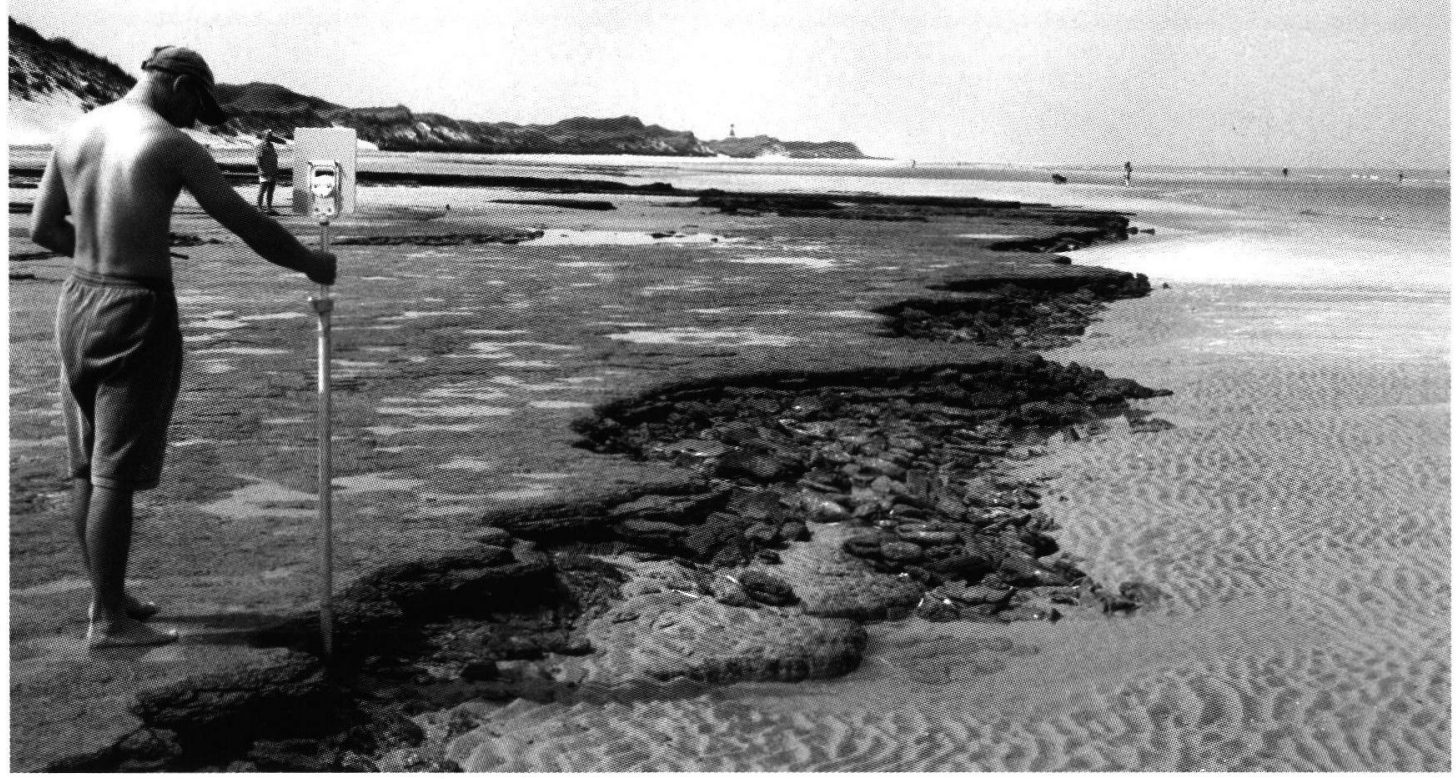

Fig. 2: Salt-marsh deposits exposed on the beach of the seaward side of the island of Juist due to coastal erosion and shoreline displacement. 
Tab. 1: Geographical position of study sites

$\begin{array}{llll}\text { Profile } & \text { Height }[\mathrm{NN}+\mathrm{m}] & \text { Geographical position } & \text { Map sheet 1:25.000 } \\ \text { Loxstedt } & +3.75 \mathrm{~m} & 53^{\circ} 43^{\prime} \mathrm{N}, 8^{\circ} 50^{\prime} \mathrm{E} & 2517 \text { Loxstedt } \\ \text { Schweiburg } & +2.00 \mathrm{~m} & 53^{\circ} 39^{\prime} \mathrm{N}, 8^{\circ} 26^{\prime} \mathrm{E} & 2516 \text { Nordenham } \\ \text { Wangerland 2 } & +0.65 \mathrm{~m} & 53^{\circ} 62^{\prime} \mathrm{N}, 7^{\circ} 96^{\prime} \mathrm{E} & 2313 \text { Wangerland } \\ \text { Wangerland 5 } & +2.00 \mathrm{~m} & 53^{\circ} 60^{\prime} \mathrm{N}, 7^{\circ} 94^{\prime} \mathrm{E} & 2513 \text { Wangerland } \\ \text { Juist 3 } & +1.40 \mathrm{~m} & 53^{\circ} 40^{\prime} \mathrm{N}, 6^{\circ} 53^{\prime} \mathrm{E} & 2307 \text { Juist West } \\ \text { Juist 6 } & +0.78 \mathrm{~m} & 53^{\circ} 40^{\prime} \mathrm{N}, 6^{\circ} 54^{\prime} \mathrm{E} & 2307 \text { Juist West } \\ \text { Juist 18 } & +0.72 \mathrm{~m} & 53^{\circ} 40^{\prime} \mathrm{N}, 6^{\circ} 40^{\prime} \mathrm{E} & \text { 2307 Juist West } \\ \text { Borkum } & +1.00 \mathrm{~m} & 53^{\circ} 35^{\prime} \mathrm{N}, 6^{\circ} 41^{\prime} \mathrm{E} & \text { U3000 Borkum } \\ \text { Langeoog 3 } & +2.80 \mathrm{~m} & 53^{\circ} 45^{\prime} \mathrm{N}, 7^{\circ} 29^{\prime} \mathrm{E} & 2210 \text { Langeoog West }\end{array}$

(Müller 1977). The Schweiburg drill site, E of the Jade bay (Fig. 1) is situated in what may be a tidal bay. The Wangerland drill site lies approximately $18 \mathrm{~km} \mathrm{NW}$ of Wilhelmshaven in the Wangerland marshland (Core Wangerland 2 and 5; Fig. 1, Tab.1). This study area, now named Crildumer Bay, was a sheltered bay in former times but has since silted up. It was most likely subdivided by a peninsula (PETZELBERGER 1997). The cores presented in this paper are located in the southern section of the former bay.

Palaeochronological investigations into former sea-level fluctuations, based on evidence from salt-marsh and tidal flat horizons of the East Friesian Islands, have so far been carried out on Memmert, Borkum, Juist, Langeoog, Wangerooge and Mellum. In this paper results from the study sites of Borkum, Juist and Langeoog are presented (Fig. 1, Tab. 1).

Conditions for palaeoecological and geological studies are most favourable on the seaward side of Juist as palaeohorizons are particularly well exposed (Juist profiles 3, 6 and 18; Tab. 1, Freund \& Streif 1999, 2000; Freund 2003, Freund et al. 2003; 2004). These salt marshes were originally formed on the landward side of the island but were blanketed and preserved by dune sand following a north-south dislocation.
Coastal erosion and shoreline displacement has lead to the exposure of these deposits in more recent times (Fig. 2). The Borkum profile (profile "Am Hopp") is located in a recent salt-marsh area south of the town of Borkum (Tab. 1).

The search for the most complete sequence of salt marsh and tidal flat deposits was carried out with a hand driven corer. On Langeoog the sampling site is situated near the centre of the village of Langeoog. During the geological survey of the 1960's two intercalated organic layers, most likely indicating variations in island development, were described by BARCKHAUSEN (1969). At present the availability of suitable coring sites is restricted as many promising areas have been built-over. Nevertheless, a small area of fallow land in the centre of the village has produced one organic horizon (profile 3 "Kiebitzweg", Tab. 1). The survey followed the method used on Borkum. On all islands samples were extracted from excavated holes using metal sampling boxes.

\section{Material and Methods}

Diatoms were separated according to SCHRADER (1973). Counts were obtained using a Zeiss Axiophot microscope under phase contrast at 
x1000 magnification, thus providing data on relative abundance. Frequencies are expressed as percentages of the total number of diatom valves counted (TDV; minimum of 200 valves in each sample). Counts of samples of $0.1-1 \mathrm{ml}$ volume (depending on the suspension) were made in triplicate using counting chambers (UTERMÖHL 1958) under an inverted microscope ( $x 400$ magnification). If no diatoms were found by applying the above method, the following procedure was used. Samples were homogenized and dried, treated with $15 \%$ hydrogen peroxide for one hour, suspended in water and sieved through $500 \mu \mathrm{m}$ and $63 \mu \mathrm{m}$ mesh. The resulting fractions were dried for $12 \mathrm{~h}$ at $60^{\circ} \mathrm{C}$. Diatoms were analysed in subsample triplicates of $500 \mathrm{mg}$ minimum. Those of the $>63 \mu \mathrm{m}$ fraction were counted at $\times 200$ magnification using a Zeiss Stemi SV 11 binocular microscope. Diatoms were identified using Drebes (1974), Hustedt (1957) and Pankow (1990). Nomenclature fol- lows Hartley et al. (1996).

The diatom species were divided into groups depending on salinity tolerance according to SimONSEN (1962): (i) polyhalobous-marine taxa $(-30 \%)$, (ii) mesohalobous-brackish taxa $(0.2-30 \% 0)$, and (iii) oligohalobous taxa (0$20 \%$ ). Halophilous and indifferent taxa can tolerate brackish and freshwater conditions, but the former have their optimum in brackish water while the latter are regarded as having their optimum in freshwater conditions. An extended classification is based on VOS \& DE WoLF (1993), in which diatoms are classified in relation to their saline optimum and according to their specific sedimentary environments.

Diatom counts are plotted using the TILIA graph program by Grimm (1993).

A total of 188 taxa were identified in 523 samples taken from the four cores of the landward study sites. Of the material from the East Friesian Islands 166 analyses were carried out

Tab. 2: Dominant diatom taxa (exceeding 5\% TDV) recorded from the nine coastal sites with their salinity classes, life forms and subfossil and recent habitats indicated.

\begin{tabular}{|c|c|c|c|c|c|c|c|}
\hline $\begin{array}{l}\text { distribution } \\
\text { fossil }\end{array}$ & Species & $\begin{array}{c}\text { habitat } \\
\text { littoral } \\
\text { or } \\
\text { pelagic }\end{array}$ & halob & haline & $\begin{array}{c}\text { Substrat } \\
\text { Epiphytic } \\
\text { Episammic } \\
\text { Epipelic }\end{array}$ & fragility & $\begin{array}{l}\text { distribution } \\
\text { modern }\end{array}$ \\
\hline Brackish backside lagoons & Anomoeoneis sphaerophora & littoral & oligohalobous & $\begin{array}{c}\text { mesohaline } \\
0-10 \%\end{array}$ & epipelic & silicified & $\begin{array}{l}\text { salt marsh, saline waters of the } \\
\text { hinterland }\end{array}$ \\
\hline Brackish backside lagoons & Cocconeis peltoides & littoral & polyhalobous & $\begin{array}{c}\text { mesohaline } \\
10-30 \%\end{array}$ & epiphytic & silicified & freshwater to brackish water \\
\hline Brackish backside lagoons & Cocconeis placentula & littoral & oligohalobous & $\begin{array}{c}\text { pleiohaline } \\
0-30 \%\end{array}$ & epiphytic & silicified & marine coastal waters \\
\hline $\begin{array}{l}\text { Brackish backside lagoons } \\
\text { and salt marsh }\end{array}$ & Diploneis elliptica & littoral & oligohalobous & $\begin{array}{c}\text { pleiohaline } \\
0-20 \%\end{array}$ & epipelic & strongly silicified & $\begin{array}{l}\text { salt marsh, saline waters of the } \\
\text { hinterland }\end{array}$ \\
\hline $\begin{array}{l}\text { Brackish backside lagoons } \\
\text { and salt marsh }\end{array}$ & Diploneis interrupta & littoral & mesohalobous & $0,2-10 \%$ & epipelic & strongly silicified & $\begin{array}{l}\text { salt marsh, saline waters of the } \\
\text { hinterland }\end{array}$ \\
\hline Brackish backside lagoons & Gyrosigma spenceri & littoral & mesohalobous & $10-30 \%$ & epipelic & fragile & $\begin{array}{l}\text { salt marsh, and saline waters } \\
\text { of the hinterland }\end{array}$ \\
\hline Brackish backside lagoons & Navicula capitata & littoral & oligohalobous & $\begin{array}{c}\text { mesohaline } \\
0-10 \%\end{array}$ & epipelic & silicified & inter- to supratidal zone \\
\hline Brackish backside lagoons & Navicula digitoradiata & littoral & mesohalobous & $10-30 \%$ & epipelic & silicified & inter- to supratidal zone \\
\hline Brackish backside lagoons & Navicula meniscus & littoral & oligohalobous & $\begin{array}{c}\text { mesohaline } \\
0-10 \%\end{array}$ & & silicified & brackish waters \\
\hline Brackish backside lagoons & Navicula peregrina & littoral & mesohalobous & $10-30 \%$ & epipelic & silicified & brackish waters \\
\hline Brackish backside lagoons & Navicula salinarum & littoral & mesohalobous & $3-30 \%$ & & silicified & marine coastal waters \\
\hline Brackish backside lagoons & Nitzschia brevissima & littoral & oligohalobous & $\begin{array}{c}\text { pleiohaline } \\
0-20 \%\end{array}$ & epipelic & silicified & inter- to supratidal zone \\
\hline Brackish backside lagoons & Nitzschia constricta & littoral & mesohalobous & $3-30 \%$ & epipelic & silicified & inter- to supratidal zone \\
\hline $\begin{array}{l}\text { Brackish backside lagoons } \\
\text { and salt marsh }\end{array}$ & Nitzschia sigma & littoral & mesohalobous & $10-30 \%$ & epipelic & fragile & lower supratidal zone \\
\hline $\begin{array}{l}\text { Brackish backside lagoons } \\
\text { and peat }\end{array}$ & Pinnularia major & littoral & oligohalobous & $\begin{array}{c}\text { pleiohaline } \\
0-20 \% \\
\end{array}$ & & fragile & $\begin{array}{l}\text { eutrophic freshwater, creeks } \\
\text { and lagoons }\end{array}$ \\
\hline $\begin{array}{l}\text { Brackish backside lagoons } \\
\text { and peat }\end{array}$ & Pinnularia viridis & littoral & oligohalobous & $\begin{array}{c}\text { mesohaline. } \\
0-10 \%\end{array}$ & & fragile & $\begin{array}{l}\text { eutrophic freshwater, creeks } \\
\text { and lagoons }\end{array}$ \\
\hline
\end{tabular}




\begin{tabular}{|c|c|c|c|c|c|c|c|}
\hline $\begin{array}{l}\text { Brackish backside lagoons } \\
\text { and peat }\end{array}$ & Staurosira construens & littoral & oligohalobous & $\begin{array}{c}\text { mesohaline } \\
0-10 \%\end{array}$ & & strongly silicified & freshwater lagoons \\
\hline $\begin{array}{l}\text { Brackish tidal flats and } \\
\text { lower salt marsh }\end{array}$ & Caloneis aemula & littoral & mesohalobous & $\begin{array}{c}\text { pleiohaline } \\
3-30 \%\end{array}$ & & silicified & marine coastal waters \\
\hline $\begin{array}{l}\text { Brackish tidal flats and } \\
\text { lower Salt marsh }\end{array}$ & Caloneis formosa/westii & littoral & mesohalobous & $\begin{array}{c}\text { pleiohaline } \\
3-30 \%\end{array}$ & & silicified & brackish tidal flats \\
\hline Brackish tidal flats & Fallacia forcipata & littoral & polyhalobous & $\begin{array}{c}\text { mesohaline } \\
10-30 \% \\
\end{array}$ & epipelic & silicified & $\begin{array}{l}\text { sandy tidal flats, brackish to } \\
\text { marine tidal flat }\end{array}$ \\
\hline Brackish tidal flats & Navicula cincta & littoral & oligohalobous & $\begin{array}{c}\text { pleiohaline } \\
0-20 \%\end{array}$ & $\begin{array}{c}\text { epipelic/ } \\
\text { aerophilous }\end{array}$ & silicified & inter- to supratidal zone \\
\hline Brackish tidal flats & Navicula pygmaea & littoral & mesohalobous & $0,2-10 \%$ & epipelic & fragile & brackish water \\
\hline Dune slack & Cymbella aspera & littoral & oligohalobous & $\begin{array}{l}\text { pleiohaline. } \\
0-20 \%\end{array}$ & $\begin{array}{l}\text { epipelic/ } \\
\text { aerophilous }\end{array}$ & silicified & freshwater \\
\hline Dune slack & $\begin{array}{l}\text { Epithemia zebra var. } \\
\text { porcellus }\end{array}$ & littoral & oligohalobous & $\begin{array}{c}\text { mesohaline } \\
0-20 \%\end{array}$ & epiphytic & silicified & freshwater \\
\hline Dune slack & Navicula menisculus & littoral & mesohalobous & & & silicified & brackish waters \\
\hline Dune slack & Navicula variostriata & littoral & oligohalobous & indifferent & & silicified & swamps \\
\hline Dune slack & $\begin{array}{l}\text { Staurosira construens var. } \\
\text { subsalina }\end{array}$ & littoral & oligohalobous & $\begin{array}{c}\text { pleiohaline } \\
0-20 \% 0\end{array}$ & & silicified & freshwater and brackish \\
\hline $\begin{array}{l}\text { Fluvial levee and and tidal } \\
\text { flat }\end{array}$ & Cyclotella meneghiniana & pelagic & oligohalobous & $\begin{array}{c}\text { pleiohaline } \\
0-20 \%\end{array}$ & & strongly silicified & $\begin{array}{l}\text { river estuaries } \\
\text { (Weser) }\end{array}$ \\
\hline Salt marsh & Diploneis bombus & littoral & polyhalobous & $\begin{array}{c}\text { mesohaline } \\
15-35 \%\end{array}$ & epipelic & strongly silicified & interdial to supratidal zone \\
\hline Salt marsh and dune slack & Hantzschia amphioxys & littoral & oligohalobous & & & & \\
\hline Salt marsh (high) & Navicula pusilla & littoral & oligohalobous & $\begin{array}{c}\text { mesohaline } \\
0-10 \%\end{array}$ & $\begin{array}{c}\text { epipelic/ } \\
\text { aerophilous }\end{array}$ & silicified & freshwater and brackish water \\
\hline Salt marsh (high) & Navicula mutica & littoral & oligohalobous & $\begin{array}{c}\text { mesohaline } \\
0-10 \% \text { }\end{array}$ & $\begin{array}{c}\text { epipelic/ } \\
\text { aerophilous }\end{array}$ & silicified & freshwater and brackish water \\
\hline $\begin{array}{l}\text { Salt marsh and lagoonal } \\
\text { deposits }\end{array}$ & Scolioneis tumida & littoral & mesohalobous & $10-30 \%$ & epipelic & silicified & sandy to muddy tidal flats \\
\hline Salt marsh & Tryblionella apiculata & littoral & mesohalobous & $0,5-30 \%$ & epipelic & silicified & inter- to supratidal zone \\
\hline $\begin{array}{l}\text { Salt marsh and lagoonal } \\
\text { deposits }\end{array}$ & Tryblionella apiculata & littoral & mesohalobous & $0,5-30 \%$ & epipelic & silicified & inter- to supratidal zone \\
\hline $\begin{array}{l}\text { Salt marsh and lagoonal } \\
\text { deposits and tidal flats }\end{array}$ & Tryblionella navicularis & littoral & polyhalobous & $7-30 \%$ & epipelic & strongly silicified & inter- to supratidal zone \\
\hline Tidal flat & Achnanthes delicatula & littoral & polyhalobous & $\begin{array}{c}\text { pleiohaline } \\
3-30 \%\end{array}$ & epipsammic & strongly silicified & subtidal to intertidal \\
\hline Tidal flat & Actinoptychus senarius & pelagic & polyhalobous & $\begin{array}{c}\text { mesohaline } \\
10-30 \%\end{array}$ & & silicified & coastal waters \\
\hline Tidal flat and peat & Aulacodiscus argus & pelagic & polyhalobous & indifferent & & strongly silicified & obligate sublittoral, open sea \\
\hline Tidal flat & Cymatosira belgica & littoral & polyhalobous & $\begin{array}{c}\text { meiohaline } \\
20-30 \% \text { o }\end{array}$ & epipelic & silicified & tidal flat \\
\hline Tidal flat & Delphineis surirella & littoral & polyhalobous & $\begin{array}{c}\text { meiohaline } \\
20-30 \%\end{array}$ & epipelic & strongly silicified & tidal flat \\
\hline Tidal flat and salt marsh & Diploneis smithii & littoral & polyhalobous & $\begin{array}{c}\text { pleiohaline } \\
3-30 \%\end{array}$ & epipelic & strongly silicified & $\begin{array}{l}\text { salt marsh, tidal flat and saline } \\
\text { waters of the hinterland }\end{array}$ \\
\hline Tidal flat & Opephora pacifica & littoral & polyhalobous & indifferent & epipelic & silicified & marine coastal zone \\
\hline $\begin{array}{l}\text { Tidal flat, natural and fluvial } \\
\text { levee, peat }\end{array}$ & Paralia sulcata & pelagic & polyhalobous & $\begin{array}{c}\text { mesohaline } \\
10-30 \%\end{array}$ & & strongly silicified & marine coastal waters \\
\hline Tidal flat & Raphoneis amphiceros & littoral & polyhalobous & $\begin{array}{c}\text { mesohaline } \\
10-30 \%\end{array}$ & $\begin{array}{l}\text { epipelic to } \\
\text { epipsammic }\end{array}$ & strongly silicified & tidal flat \\
\hline Tidal flat and peat & Triceratium favus & pelagic & polyhalobous & indifferent & & strongly silicified & obligate sublittoral open sea \\
\hline
\end{tabular}

yielding a total of 133 taxa. In Table 2, the species with an abundance of more than $5 \%$ are listed and classified according to their habitat, salinity tolerance, substrate specificity and their distribution in both modern and palaeocoastal areas. All dates mentioned in the text are radiocarbon dates; dates cited as $\mathrm{AD} / \mathrm{BC}$ are calibrated dates.

\section{Results}

Although all sampling sites are situated around the southern North Sea they provide evidence for both environmental and temporal variations. The cores located in the vicinity of the Pleistocene hinterland embrace the coastal development of the entire Holocene, reflecting "on shore" sedimentation conditions. A more or less "off shore" environment is indicated by 
the sampling sites on the East Friesian Islands which mirror the youngest coastal developments of the North Sea only. Consequently, the results are initially presented separately and then brought together comprehensively.

\subsection{Environmental interpretation of the borehole units of the Pleistocene hinterland}

Basal peat, intercalated peat: Most basal peat units are characterized by a transition from carr to reed or sedge peat. An exception is Wangerland core W5 which records a change to bog peat (Dellwig et al. 1999).

The concentration of diatoms in the basal organic rich deposits varies rather widely. In the Loxstedt core, diatoms are absent in the lowermost part of the basal peat. Only the freshwater mud (Fig. 3) contains fragments of large Pinnularia species (Dellwig 1999) indicating limnic conditions. The upper part of the basal peat is characterized by the oligohalobous to freshwa- ter species Staurosira construens. In addition, low numbers of strongly silicified polyhalobous pelagic diatoms, such as Triceratium favus and Aulacodiscus argus (not shown), were recorded. These indicate sea-water impact, possibly due to a single flood event. With regard to the diatom assemblages it is obvious that the basal peat of the Loxstedt core developed under limnic conditions. By contrast the basal peat of the Wangerland core W2 (Fig. 4) received much more marine influence. Here the number of species is significantly higher than in the basal peat of the Loxstedt core, and brackish species, such as the mesohalobous Nitsscbia constricta and the fragile N. sigma are dominant. In particular, $N$. sigma is an indicator of calm depositional conditions typical of the lower supratidal zone. Nevertheless, the presence of strongly silicified polyhalobous pelagic species like Paralia sulcata suggests flood events. Similarly the basal peat of the Schweiburg core (Fig. 6) was also influenced by the North Sea. This is evident from the high numbers of strongly silicified allochthonous marine pelagic diatoms in the entire peat accu-

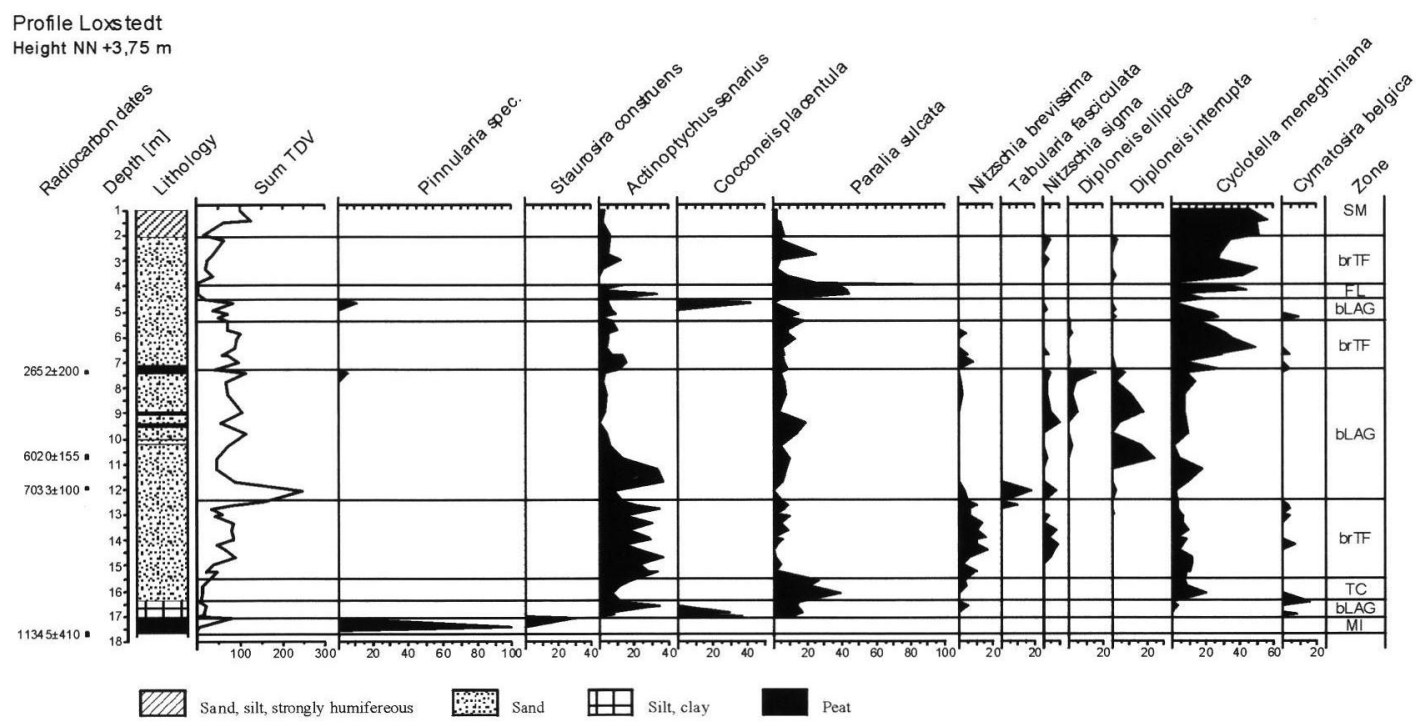

Fig. 3: Diatom diagram showing frequencies of major diatom taxa of the Loxstedt core. (SM = salt marsh; $\mathrm{FL}$ = fluvial levee; $\mathrm{TC}=$ tidal channel; brTF = brackish tidal flat; $\mathrm{bLAG}=$ brackish backside lagoon; $\mathrm{MI}=$ mire). 
Profile Wangerland 2

Height $\mathrm{NN}+0,65 \mathrm{~m}$

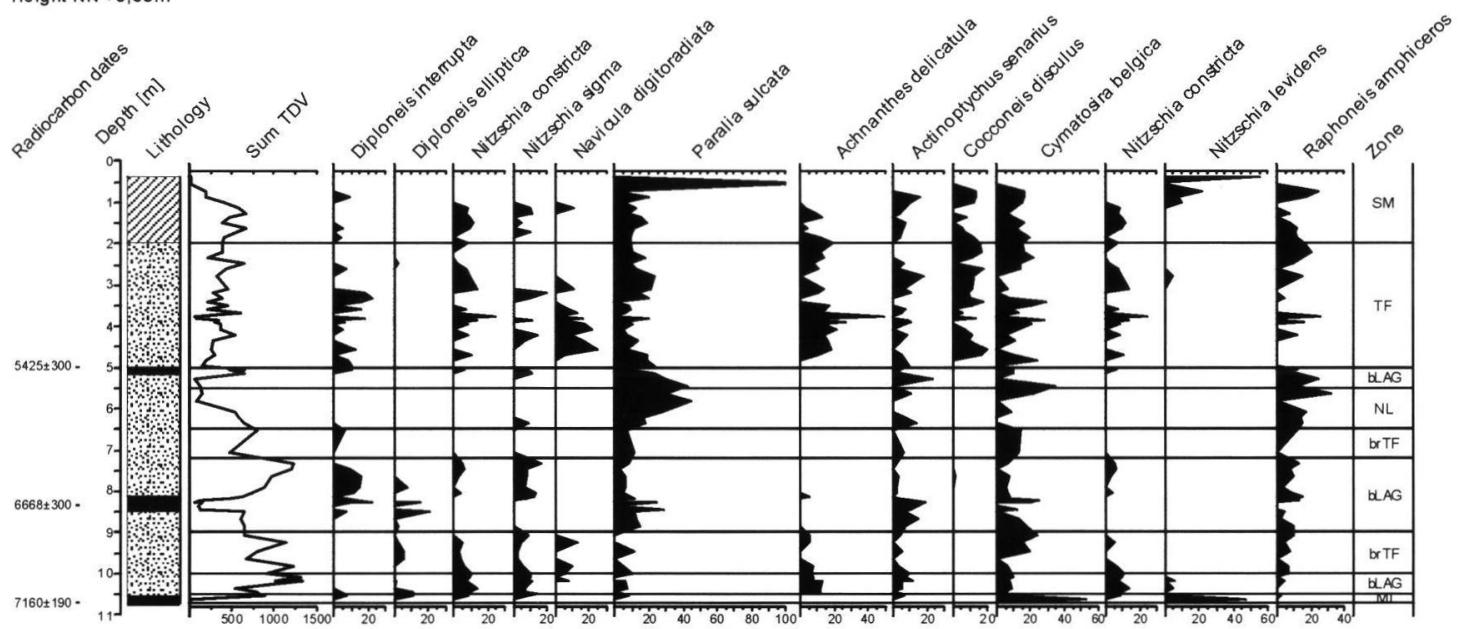

Sand, silt, strongly humifereous

Peat

Fig. 4: Diatom diagram showing frequencies of major diatom taxa of the Wangerland W2 core. (SM = salt marsh; $\mathrm{NL}=$ natural levee; $\mathrm{TF}=$ tidal flat; $\mathrm{brTF}=$ brackish tidal flat; bLAG = brackish backside lagoon; MI $=$ mire).

mulation. The biostratigraphy of the basal peat units of the Wangerland and Schweiburg cores, comprising meso- and polyhalobous diatoms, indicate brackish lake conditions periodically invaded by sea water. These basal peats accumulated under marine influence, whereas those of the Loxstedt core developed independent of marine influence and sea-level rise.

The clastic coastal deposits of the Schweiburg, Loxstedt and Wangerland W2 and W5 cores also contain intercalated peat layers. Most of these organic layers consist of reed peat comprising species such as Phragmites australis which tolerates a salinity of about 10\% (SCHEER 1953). However, the occurrence of Phragmites peat suggests a slow-rising or even regressive sea level. An exception is the intercalated peat of the Schweiburg borehole which shows a transition to bog vegetation, reflecting a complete progradation cycle. The topography of the natural levees in the ancient Jade Bay area may have prevented the direct inflow of seawater to this site (Dellwig 1999). Due to marine influ- ence, the intercalated peat layers are dominated by oligohalobous as well as marine pelagic diatoms.

The littoral species of the Wangerland core W5, Navicula capitata, Pinnularia viridis (not shown) and Anomoeoneis sphaerophora, indicate a salinity of $0-10 \%$ (Fig. 5). At present all three species reside in the supratidal salt marshes and saline waters of the hinterland. Oligohalobous species such as Diploneis interrupta are dominant in the intercalated peat layers of Wangerland core W2 (Fig. 4), and highly abundant in corresponding layers of the Loxstedt core (DELLwIG 1999). In contrast, the intercalated peat layers of the Schweiburg core are characterized by the frequent occurrence of littoral polyhalobous and mesohalobous species with a wide salinity range, e.g. Nitzschia navicularis and $N$. sigma. However, diatom assemblages in all intercalated peat layers were influenced by allochthonous marine pelagic species due to the proximate coastline and single flood events (e.g. Actinoptychus senarius and Paralia sulcata). In conclusion, 


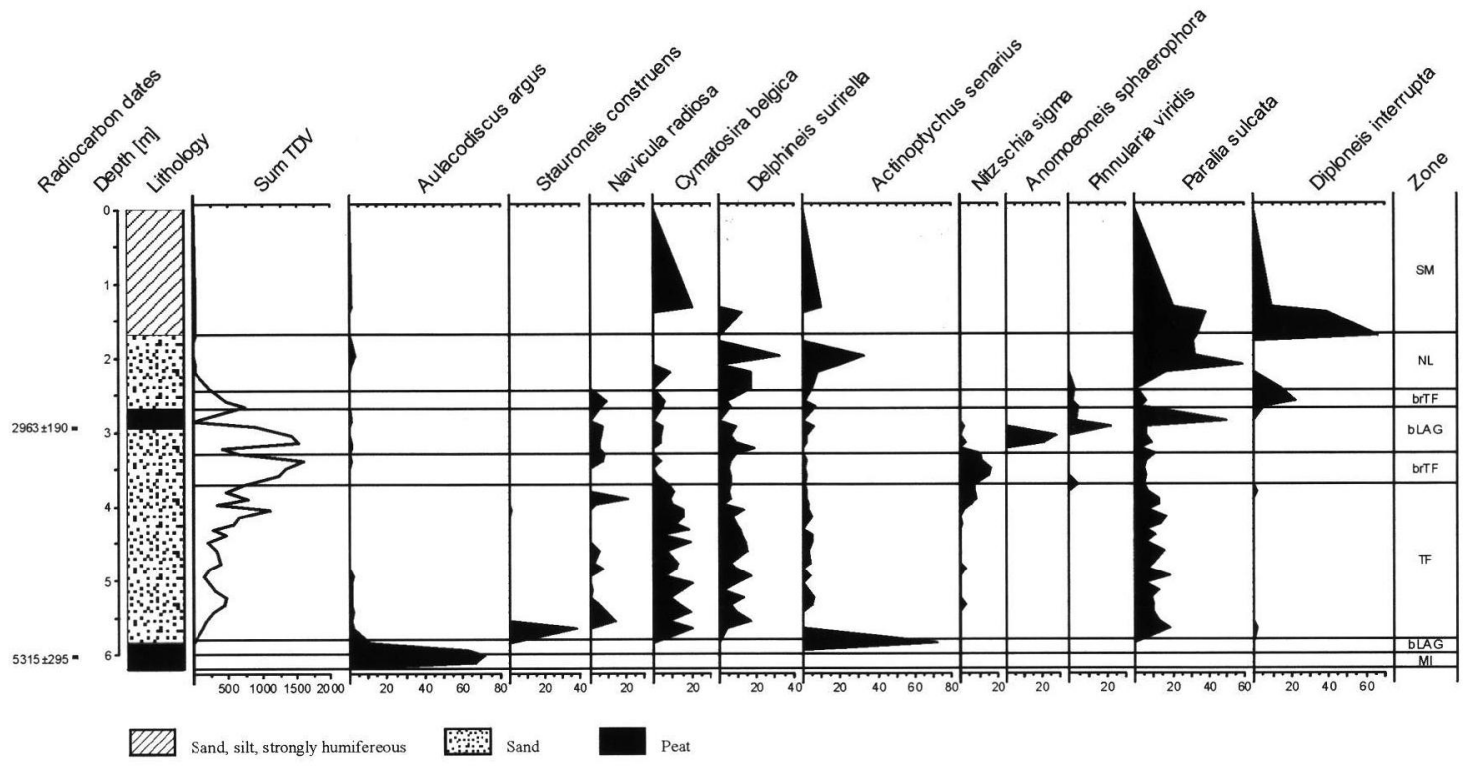

Fig. 5: Diatom diagram showing frequencies of major diatom taxa of the Wangerland W5 core. ( $S M=$ salt marsh; $\mathrm{NL}=$ natural levee; $\mathrm{TF}=$ tidal flat; $\mathrm{brTF}=$ brackish tidal flat; $\mathrm{bLAG}=$ brackish backside lagoon; $\mathrm{MI}$ $=$ mire).

the composition of these assemblages indicates palaeoenvironmental conditions with a salinity of about $10 \%$.

Tidal channel deposits: The Loxstedt borehole contains a tidal channel facies. In these deposits, the diatom record is poorly represented by a minor number of valves and taxa (Fig. 3). The assemblages are dominated by marine pelagic species, whilst the percentages of littoral diatoms are below 5\%. High current velocities and low irradiance in tidal channels provide an unsuitable habitat for littoral species. The most prominent diatom species of the tidal channel deposits of the Loxstedt core is Paralia sulcata (Fig. 3). The high quantity of polyhalobous species recorded in these deposits suggests that salinity was close to $30 \%$, which is more or less equal to the salinity level of the adjacent southern North Sea.

Tidal flat sediments: All cores contain tidal flat deposits. Samples from these sediments show diatom assemblages dominated by littoral species. Nevertheless, polyhalobous pelagic species also commonly occur. The tidal flat sediments of the Wangerland core W2 are associated with a littoral diatom assemblage typical of muddy intertidal sediments, rich in species diversity (Fig. 4). The assemblage is dominated by polyhalobous and mesohalobous littoral species such as Navicula digitoradiata, Nitzschia constricta and Nitzscbia sigma. All these species can be found growing on mud in recent intertidal to lower supratidal areas with a salinity tolerance range of 5-30\%o (Table 2). Some of the more fragile species may be autochthonous. The occurrence of Navicula digitoradiata together with Diploneis interrupta, which today lives mainly in salt marshes, suggests a palaeoenvironmental level close the mean high water.

In comparison the tidal flat sediments of Wangerland core W5 are dominated by strongly silicified polyhalobous species such as Delphineis surirella, with a salinity tolerance range of 20 - 


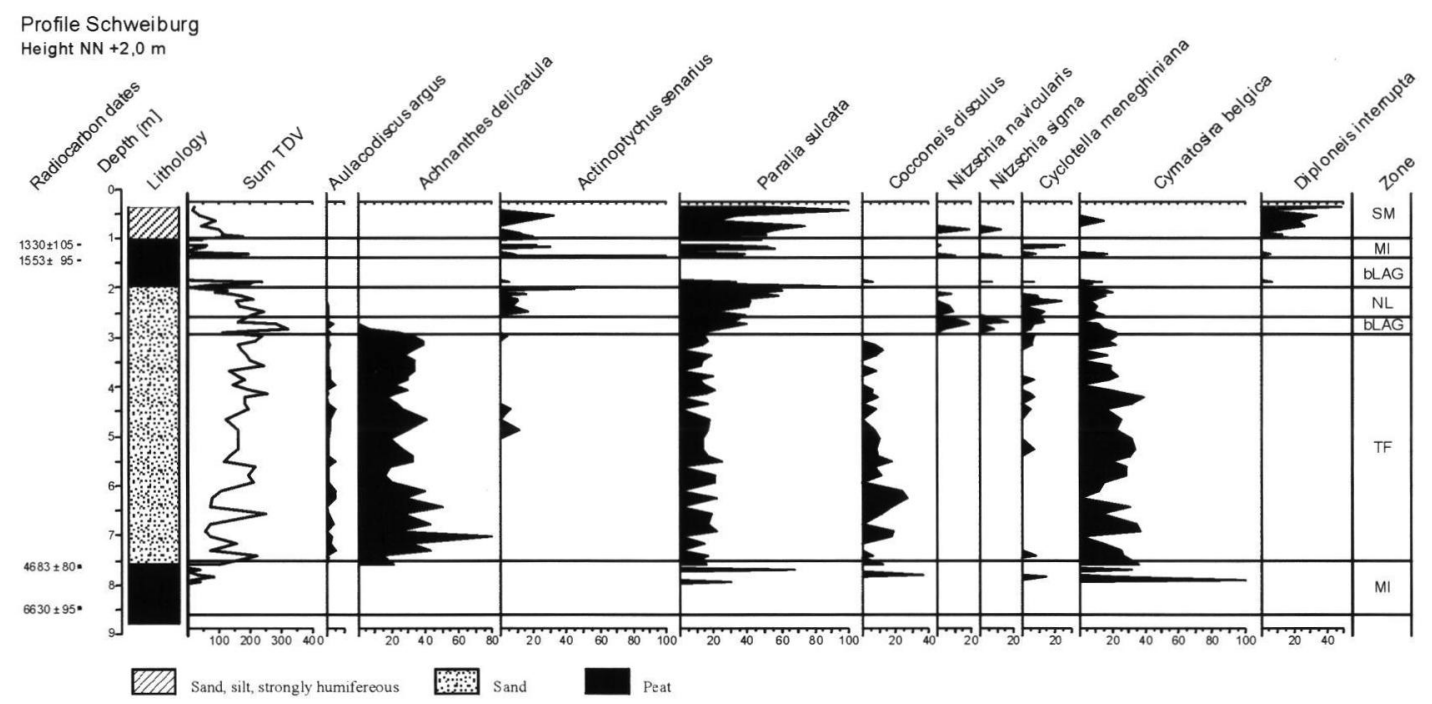

Fig. 6: Diatom diagram showing frequencies of major diatom taxa of the Schweiburg core. (SM = salt marsh; $\mathrm{NL}=$ natural levee; $\mathrm{TF}=$ tidal flat; $\mathrm{bLAG}=$ brackish backside lagoon; $\mathrm{MI}=$ mire).

$30 \%$ (Fig. 5). The relatively high percentage of polyhalobous pelagic diatoms, such as Paralia sulcata, indicates transport conditions and a continuous marine influence. Fragile littoral species of meso- and oligohalobous tolerance ranges occur only in low quantity (> 5\%). This suggests the palaeosalinity of the tidal flat was most likely higher in Wangerland core W5 (> $20 \%$ ) than in core W2 $(<20 \%$ ). Due to the position of core W2, the adjacent tidal channel had less influence on sediment accumulation.

By comparison, the diatom assemblages from the tidal flat deposits of the Loxstedt core are entirely dissimilar to those of the Wangerland cores (Fig. 3). Both upper and lower tidal flat units are dominated by pelagic diatoms. In the lower tidal flat sediments, sea-level rise is indicated by the dominance of the polyhalobous pelagic species Actinoptychus senarius. By contrast, the upper tidal flat layers are dominated by the oligohalobous pelagic species Cyclotella meneghiniana (Dellwig et al. 1998), which signifies the influence of the river Weser.

The tidal flat sequences of the Schweiburg (Fig. 6) and Wangerland W2 cores are characterized by the frequent occurrence of the littoral species $A$ chnanthes delicatula. At present, this polyhalobous species lives on the sandy sediments of the lower intertidal zone, as well as in shallow subtidal areas, providing irradiance is sufficient for photosynthetic activity (Vos \& DE Wolf 1988). The occurrence of epipsammic species, together with very low densities of mesoand oligohalobous epipelic species is typical for intertidal sand flats. Due to the relatively high hydrodynamic energy, sedimentation is limited for both clay aggregates and pelagic diatoms. Therefore the relative abundance of these species is low (Vos \& DE Wolf 1994) and the littoral species predominate. Furthermore, the relatively low numbers of diatom valves and taxa in the tidal flat deposits of the Schweiburg core confirm temporarily higher energy conditions. Fragile species, if once present, may not have survived or may be poorly represented due to subsequent reworking of sediments.

Brackish tidal flat: In addition to tidal flat deposits with polyhalobous conditions, the majority of investigated cores also contain brackish deposits. A general increase of littoral species is clearly visible in these sediments. Among these, the number of polyhalobous diatoms decreases, while mesohalobous species increase. Further- 
more, fragile forms show higher abundances. This suggests that the hydrodynamic energy was rather low in comparison to the polyhalobous tidal flat deposits mentioned above.

In the Loxstedt core, brackish deposits in the lower clastic unit are dominated by the littoral species Nitzschia sigma and N. brevissima (Fig. 3), with salinity tolerance ranges of $10-30 \%$ and $0-20 \%$, respectively. The overlapping tolerance ranges of these species suggest saline conditions of $<20 \%$. This is supported by the occurrence of the fragile mesohalobous littoral species Gyrosigma spenceri (tolerance range 10-30\%o). Fragile diatoms represent more than $40 \%$ of the total assemblage, thus suggesting calm depositional conditions. The species combination N. sigma and G. spenceri points to intertidal to lower supratidal mudflat conditions (Vos \& DE Wolf 1988). The brackish deposits of the upper clastic unit of the Loxstedt core can be interpreted as a fluvially influenced brackish or even lagoonal palaeoenvironment of low salinity, calm hydrodynamic conditions and clear water, a view that is supported by the presence of the oligohalobous epiphytic species Cocconeis placentula.

The two brackish layers of Wangerland core W5 are both characterized by high numbers of taxa. The brackish layer in the upper clastic unit contains several valves (Fig. 5). The dominant species of the lower brackish layer, Navicula radiosa (not shown), is sensitive to salinities higher than 20\%o (Pankow 1990). The upper brackish layer is characterized by the occurrence of mesohalobous species, such as Nitzschia sigma, which indicate mud-enriched sediments close to or above the mean high water level and a salinity of ca $20 \%$ (Dellwig 1999).

In the lower clastic unit of Wangerland core W2, Navicula digitoradiata and Diploneis elliptica (Fig. 4) dominate the brackish sediments. Both are epipelic species that tolerate a wide salinity range $(0-20 \%)$. Today, they occur in the intertidal to lower supratidal zone. In the upper clastic unit of the W2 core, the brackish deposits are dominated by Tryblionella navicularis (not shown). This species also tolerates a wide salinity range $(7-30 \%)$. It occurs together with Diploneis smitbii and D. interrupta, both of low abundance. In these brackish layers the portion of polyhalobous species such as Paralia sulcata, is higher than in the lower brackish layer, indicating a stronger marine influence. In summary, the brackish deposits are in general characterized by high values of mesohalobous littoral diatoms and those polyhalobous species which tolerate a wide range of salinities.

Brackish backside lagoons: The lagoonal layers are also characterized by calm depositional conditions and a limited marine influence. Littoral polyhalobous and mesohalobous species decrease by comparison to the brackish deposits, whereas oligohalobous littoral diatoms increase. It is noteworthy that in the Loxstedt and Schweiburg cores, limnic diatoms also occur in the lagoonal deposits thereby indicating freshwater influence or episodic limnic conditions.

The lower lagoonal section of the W5 core (Fig. 5 ) is dominated by Staurosira construens, which is characteristic of shallow lakes and ponds with a salinity $<5 \%$ (Vos \& DE Wolf 1994). In the lagoonal facies of the W5 upper clastic unit, oligohalobous diatoms with salinity tolerance ranges of $0-10 \%$ are frequent, e.g. Anomoeoneis sphaerophora and Navicula capitata.

In the lagoonal facies of the lower and upper clastic units of the Loxstedt core, epiphytic species are frequent, e.g. the oligohalobous diatom Cocconeis placentula (Fig. 3). The presence of epiphytic diatoms points to a submerged environment with limited marine influence. The lagoonal layer in the middle part of the Loxstedt core is dominated by the littoral oligohalobous species Diploneis elliptica and D. interrupta. Both indicate restricted marine influence, which is typical for brackish water in the hinterland.

The diatom assemblage of the lagoonal sedi- 
ments of Wangerland core W2 is similar to that of the lagoonal deposits in the Loxstedt core (Fig. 3, 4). Both layers are dominated by Diploneis species. Furthermore, Nitzschia sigma is frequent in both lagoonal deposits. Due to the dominance of Diploneis species, the palaeoenvironment may be interpreted as a muddy area in the supratidal zone with restricted marine influence.

Generally, the lagoonal sediments are characterized by high values of fragile littoral species. The highest abundance of diatoms of all sediments in this study was found here.

Salt-marsh deposits: The top of all investigated cores consist of salt-marsh sediments. In these layers, the number of valves and taxa are rare in comparison to the lagoonal facies. Most salt-marsh deposits are dominated by allochthonous marine pelagic species such as Paralia sulcata. Their occurrence may be related to single flooding events. In all cores, the predominant littoral species is Diploneis interrupta. This epipelic species, which tolerates a salinity range of $0.2-10 \%$, currently lives in the brackish pools of salt marshes and hinterland areas which can periodically dry out.

Natural and fluvial levees: Natural levees mainly consist of sand accumulated in the supratidal zone. These elevated levees, deposited during higher storm floods, are usually bordering the shoreline. However, fluvial levees with an average width of $1.5 \mathrm{~km}$ form a type of embankment along the rivers Ems, Weser and Elbe (Streif 1990). The Schweiburg and Wangerland W2 and W5 cores include natural levee sediments (Fig. 4-6), whereas only the Loxstedt core contains sediments of a fluvial levee from the river Weser (Fig. 3). These sediments are dominated by pelagic polyhalobous and oligohalobous pelagic species of allochthonous origin. The predominant diatom species in this section is Cyclotella meneghiniana which today is also the typical species of the river Weser. Marine pelagic diatoms, such as Paralia sulcata and Actinoptychus senarius, are intermixed and indicate single flooding events. The high number of allochthonous diatoms outnumbers those of autochthonous origin suggesting that the palaeoenvironment was strongly influenced by transport.

In contrast to these fluvial levee deposits, the natural levee deposits of the Wangerland cores W2 and W5 are characterized by high numbers of valves and species (Fig. 4 -6). In particular, littoral species are prevailing, predominated by the epipelic littoral species Tryblionella navicularis and Nitsschia sigma, which tolerate a wide range of salinities. They may indicate areas behind a natural levee protected from marine influence. According to the diatom assemblages, a poorlydrained supratidal environment is assumed in which very shallow pools developed. Nevertheless, allochthonous pelagic species such as Paralia sulcata also occur in these sediments, thus reporting transport processes on the occasion of high tides and storm events.

\subsection{Environmental interpretation of the profiles from the East Friesian Islands}

Palaeoecological studies on the East Friesian Islands were carried out for the reconstruction of former sea-levels. Salt-marsh horizons and tidal flat sediments are key sources of evidence as they provide material that is amenable to radiocarbon dating and also offer the opportunity for palaeoenvironmental reconstruction by their content of macro- and microfossils (including diatoms, pollen, botanical and faunal remains). The hypothesis that diatom assemblages are related to different altitudes in salt-marsh vegetation, and the proof that diatom analysis on the basis of these observations is applicable to fossil records, was demonstrated by ZoNG \& Horton (1999). 
Juist Profile $P 18$

Height: NN +0,72 m

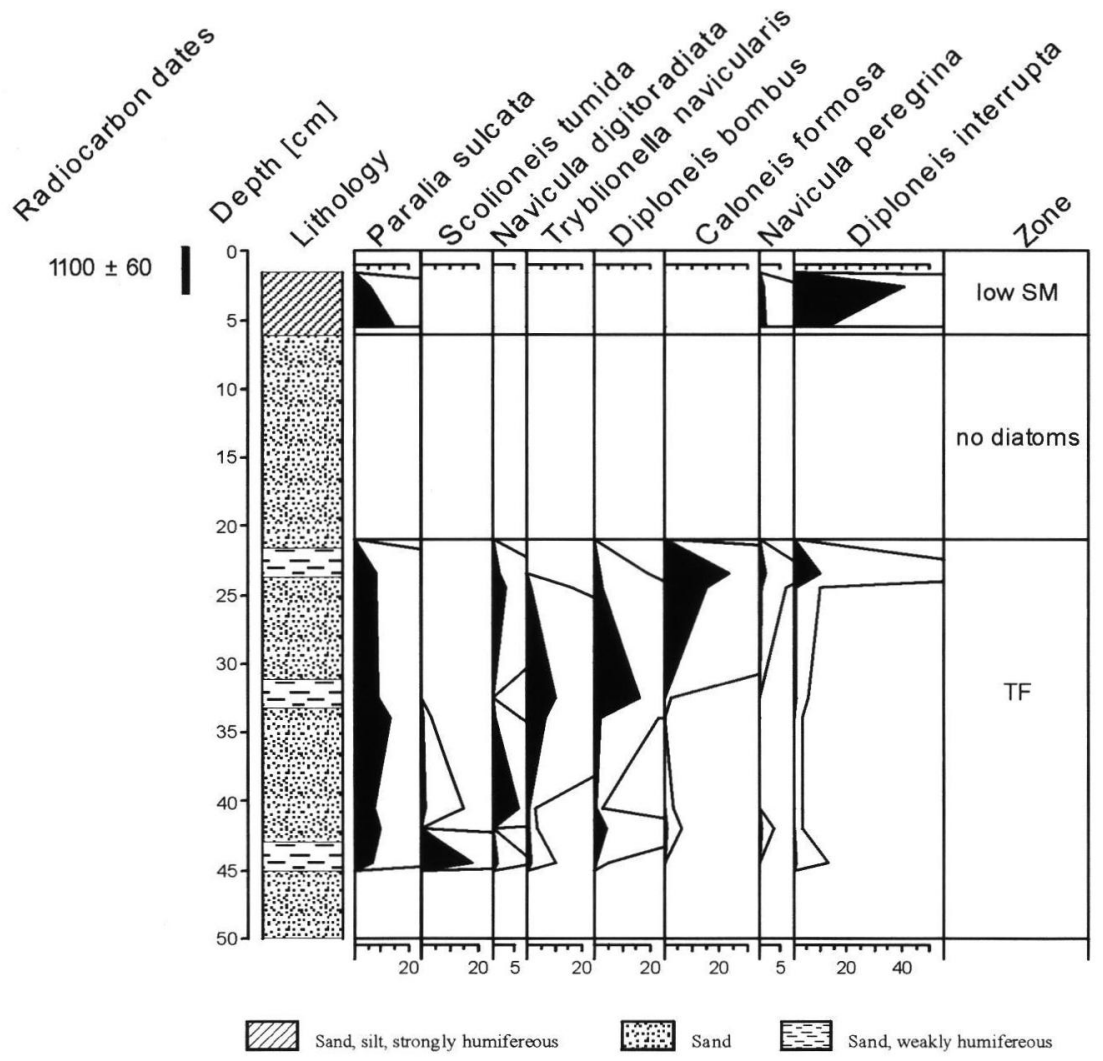

Fig. 7: Diatom diagram showing frequencies of major diatom taxa of the Juist Profile 18. Silhouette curves show diatom representation exaggerated $\mathrm{x} 10$. (low $\mathrm{SM}=$ low salt marsh; $\mathrm{TF}=$ tidal flat).

Tidal flat sediments: Tidal flat sediments occur on Juist in most of the basal sections of the profiles. They show a distinct and typical succession pattern (Fig. 7). The assemblages are dominated by frequently occurring littoral mesohalobous species, with polyhalobous pelagic species such as Paralia sulcata and Actinoptychus senarius, recorded in relatively large numbers. The most abundant littoral species in the low-lying parts of the profiles is the epipelic and mesohalobous Scolioneis tumida. This species is typical of muddy inter-tidal sediments, but is currently also abundant on sandy tidal flats in the vicinity of Juist (Hustedt 1939). The palaeoenvironment for this diatom assemblage was probably the lower part of the transition zone between intertidal and supratidal areas, with a palaeosalinity range of $5-30 \%$ o (Vos \& DE Wolf 1988). There is a certain degree of variation in the succeeding zones of tidal flat sediments in the vicinity of Juist. S. tumida is no longer the dominant taxon, whereas species such as Navicula digitoradiata and Diploneis bombus occur more frequently and in high percentages. This association, combined with Tryblionella navicularis, Diploneis elliptica or the oligohalobous pelagic species Cyclotella meneghiniana is very similar to the assemblages described for the brackish tidal flats in the vicinity of the Pleistocene hinterland in Wangerland. The latter species is very common in the water 
Borkum Profile "Am Hopp"

Height $N N+1,0 m$

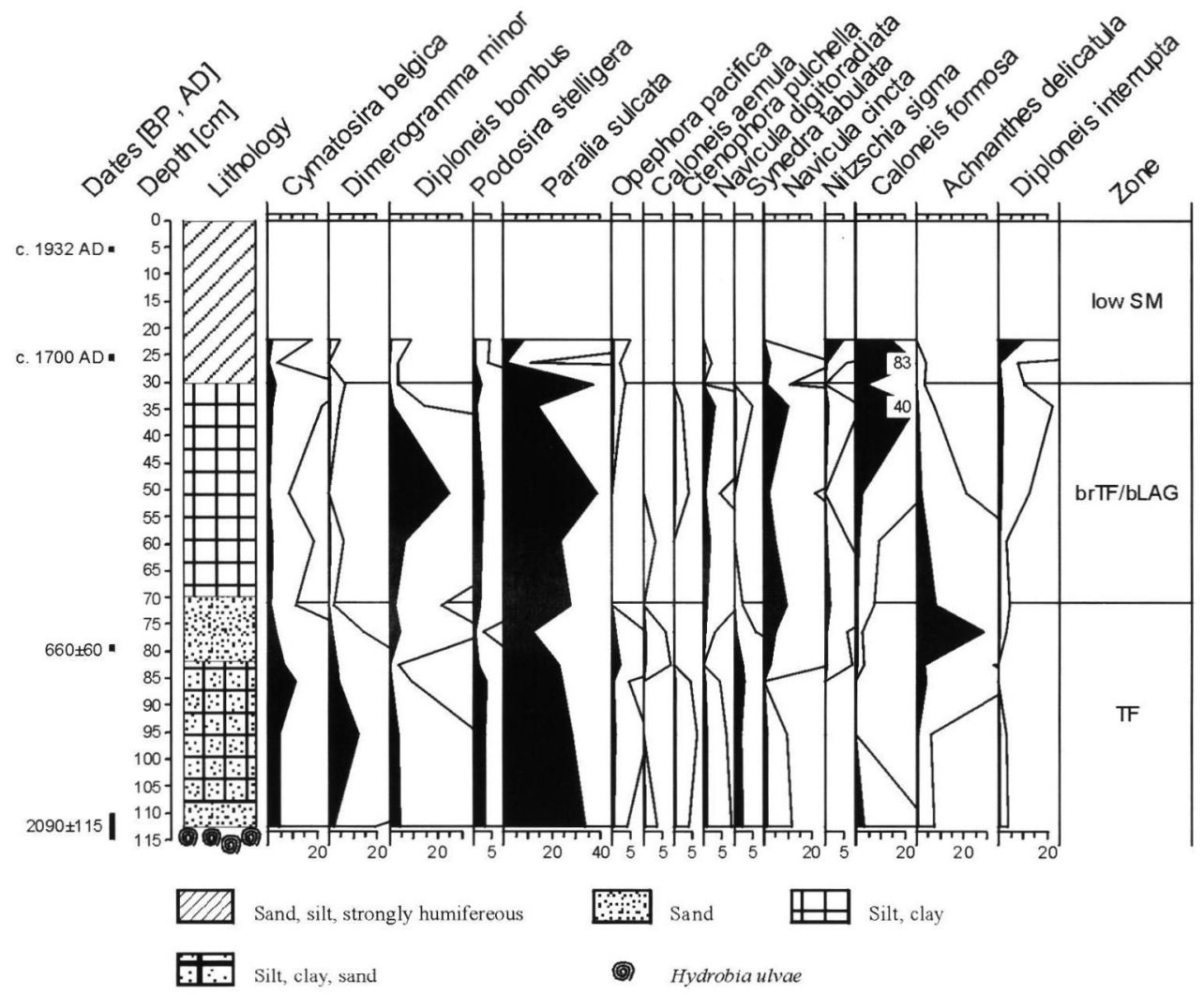

Fig. 8: Diatom diagram showing frequencies of major diatom taxa of the Borkum Profile "Am Hopp". Silhouette curves show diatom representation exaggerated $x 10$. (low $S M=$ low salt marsh; brTF $=$ brackish tidal flat, TF = tidal flat; bLAG = brackish backside lagoon).

column of the river Ems and could therefore be distributed onto the backside tidal flat of Juist through the water current of the Osterems channel, passing the island on its western side. It is suggested that at that time sedimentation took place relatively close to the supratidal zone near the mean high tide level, also characterized by the typical mean high water taxon Navicula peregrina. The next diatom assemblage zone is most likely related to the same facies. However, that it relates closer to the supratidal zone is somewhat certain, because here littoral species occur together with Diploneis interrupta which today characterizes salt-marsh habitats. Another typical element of the upper inter-tidal zone, as well as of the lower salt-marsh areas on the East Friesian islands, is Caloneis formosa (syn. Caloneis westii, Pankow 1990).

The fossil diatom record of the Borkum tidal flat sediments shows some differences in contrast to the results of Juist (Fig. 8). This may be due to the geographical position of Borkum. Although all East Friesian tidal flats are protected by the chain of barrier islands, the marine influence on Borkum, the biggest and most westerly lying East Friesian Wadden Sea island seems to be more distinct. Therefore it is understandable that the highest amounts of marine pelagic dia- 
Juist Profile 6

Height NN+0,78 m

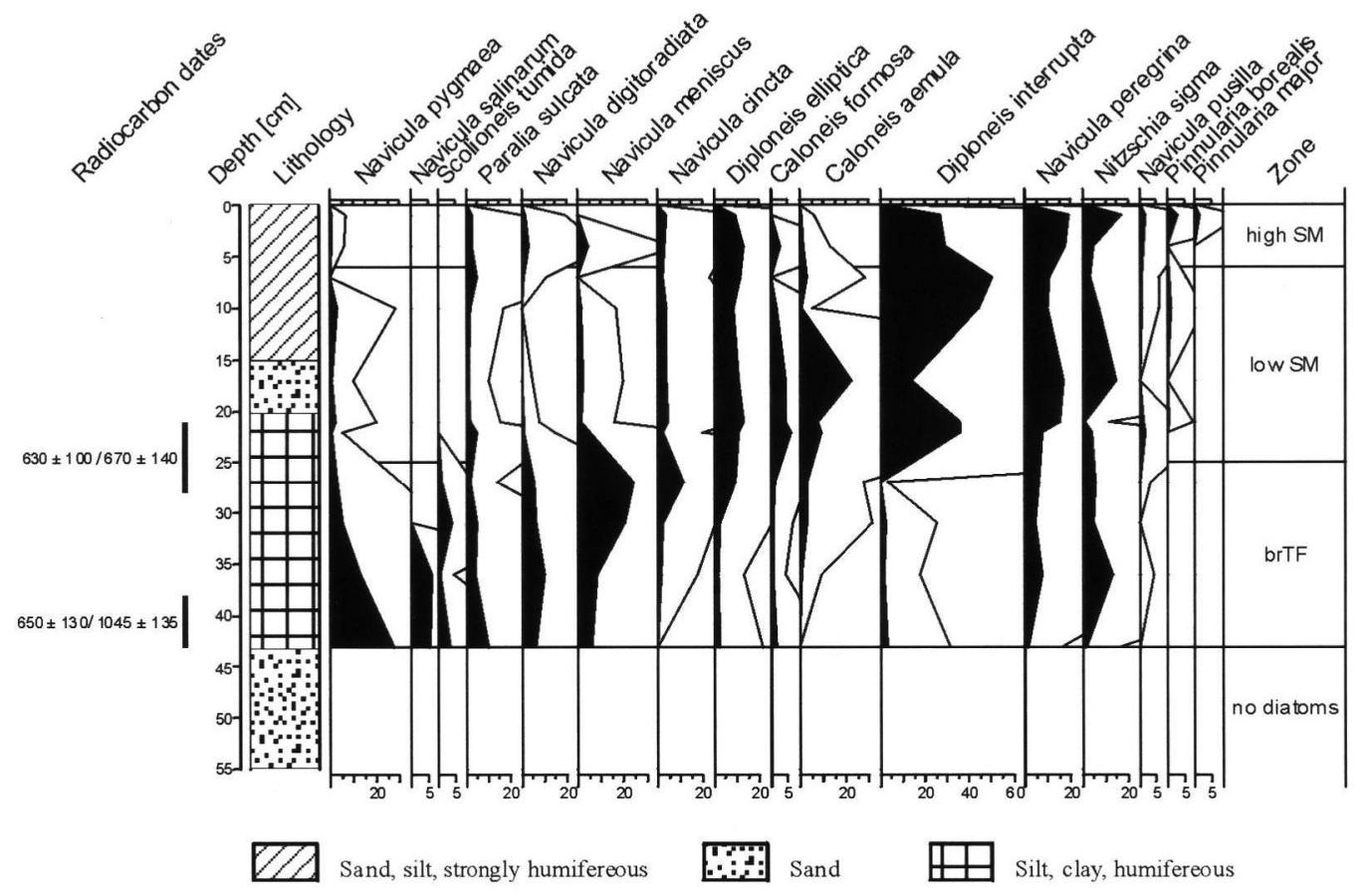

Fig. 9: Diatom diagram showing frequencies of major diatom taxa of the Juist Profile 6. Silhouette curves show diatom representation exaggerated $\times 10$. (high $\mathrm{SM}=$ high salt marsh; low $\mathrm{SM}=$ low salt marsh; brTF $=$ brackish tidal flat).

tom species such as Paralia sulcata and Podosira stelligera were recorded here. In addition, other polyhalobous species like Cymatosira belgica and Dimerogramma minor are probably representative of sandy mudflats (Fig. 8). Another typical species of the tidal flat sediments of Borkum, with values of up to $60 \%$, is Opephora pacifica (profile Borkum "Am großen Schlot", not presented in this paper). In contrast, this species was only recorded with very low values in the Juist samples. However, this polyhalobous species is at present one of the most common species in tidal flats of the North Sea. The low representation in the fossil diatom record from Juist is therefore unexpected.

A special feature of the tidal flat sequence of the profile "Am Hopp" is a distinct peak of Achnanthes delicatula, which occurs simultaneously with a decrease in percentages of Paralia sulcata. A lowering of sea level around AD 1287-1396; $660 \pm 60 \mathrm{BP}$ ) diminished marine influence and led to a localised and short-lived extension of a patchy and sparse plant cover with Salicornia, a conclusion supported by values of ca $50 \%$ for Salicornia type pollen (FreUND \& STREIF, 1999). It is most likely that the vegetation cover functioned as a sand trap that provided suitable habitat for the epipsammic species Acbnanthes delicatula on an intertidal sand flat. This hypothesis is also supported by the fact that the frequencies of pelagic and/or epipelic taxa are relatively constant but generally lower throughout this zone. The subsequent marine transgression phase shows an almost identical succession pattern as was demonstrated for the Juist tidal flat sequences, with an abundance of Diploneis 
Juist Profile 3 (height NN $+1,4 \mathrm{~m}$ )

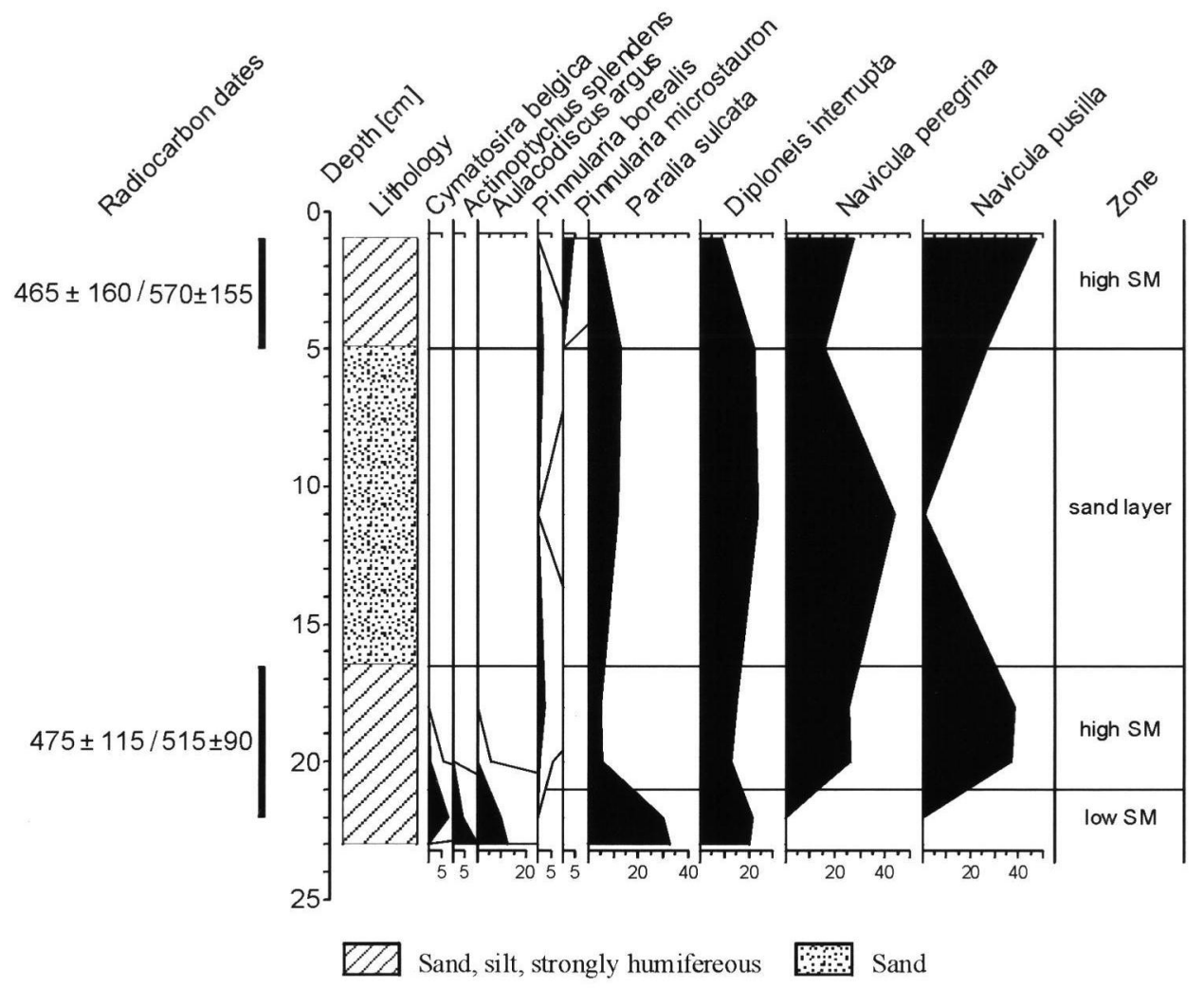

Fig. 10: Diatom diagram showing frequencies of major diatom taxa of the Juist Profile 3b. Silhouette curves show diatom representation exaggerated $\times 10$. (high $S M=$ high salt marsh; low $S M=$ low salt marsh).

bombus, Navicula digitoradiata and Caloneis formosa. The occurrence of $N$. cincta as a meso-oligohalobous species, and the associated silty sediment occurring at that time, suggests that sedimentation took place close to the supratidal area in shallow water and under calm conditions. The salinity was probably between $10-30 \%$.

Salt-marsh deposits: Although salt marshes look uniformly flat, there are clearly recognizable differences in vegetation zonation. Under natural conditions this zonation reflects soil salinity and the frequency and duration of inundation. In contrast to the salt marshes in contact with the Pleistocene hinterland, the clastic matrix of salt-marsh soils on the East
Friesian islands is relatively uniform and sandy. However, the halophytic plant communities covering these habitats are similar.

The diatom record of the low salt-marsh deposits is dominated by Diploneis interrupta, an epipelic and mesohalobous species which presently lives in brackish pools of salt marshes (Fig. 9 and 10). This taxon is often accompanied by Navicula peregrina, which normally coincides with clayey and silty sedimentation and reflects the calm conditions of sediment deposition in the low salt-marsh vegetation units. This is also supported by the occurrence of fragile, weakly silicified taxa such as Nitsschia sigma, giving this diatom assemblage a relative altitude around the local mean high water level. Most of these 


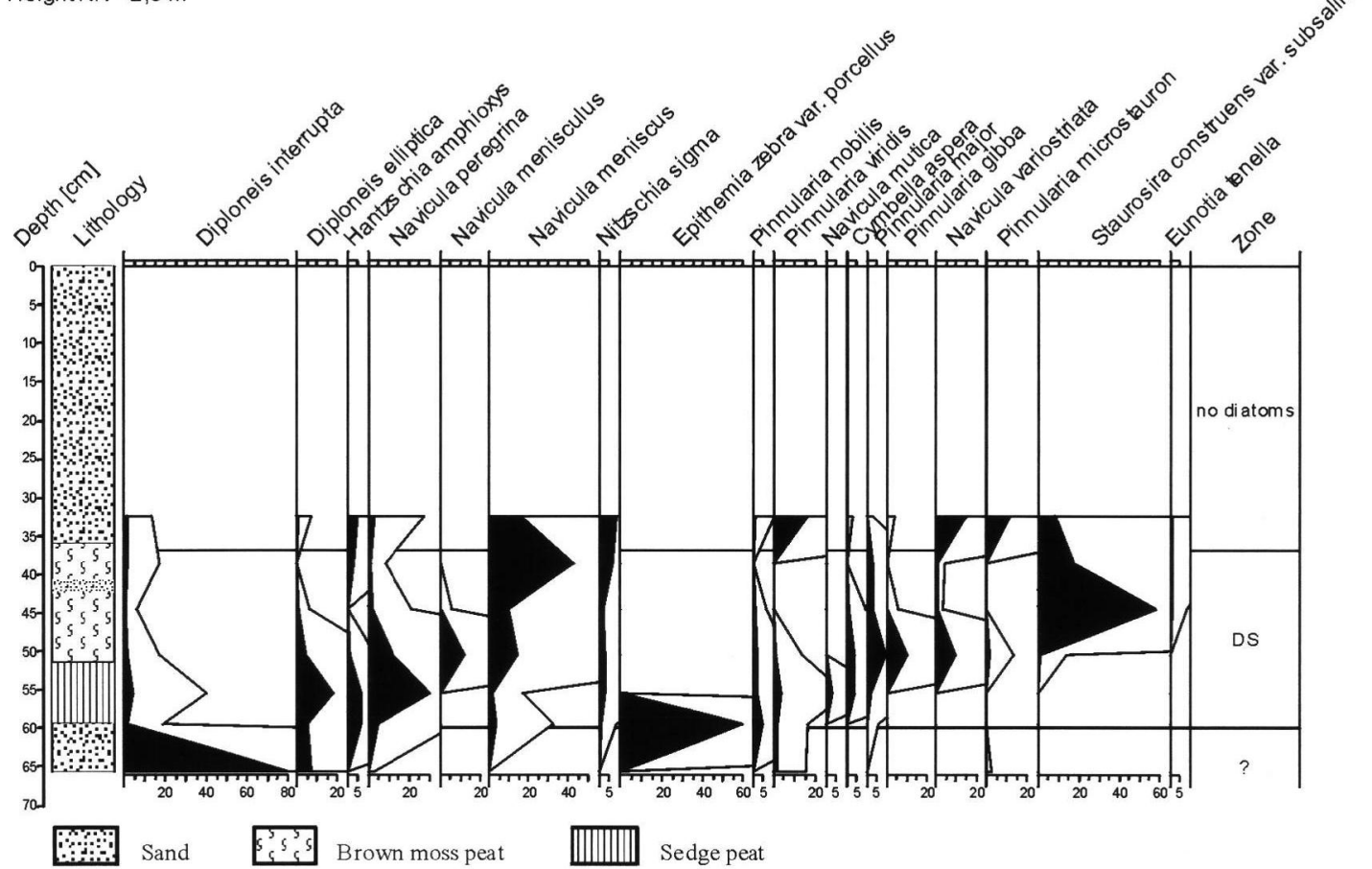

Fig. 11: Diatom diagram showing frequencies of major diatom taxa of the Langeoog Profile 3. Silhouette curves show diatom representation exaggerated $\times 10$. (DS = dune slack).

species have a wide range of salinity and can also tolerate dry periods.

The upper salt marshes are only inundated 40-70 times per year (STreif 1990). The effect of leaching rainwater is greater due to the diminished delivery of salt and therefore salinity is decreasing, reaching values of around $15 \%$. However, it has to be taken into account that the transition between lower and upper saltmarsh habitats is not sharp. Therefore, some of the low marsh and tidal flat species described above also occur in lower percentages in diatom assemblages of the upper salt marsh. A characteristic feature of this zone is the occurrence in increasing frequencies of oligohalobous species such as Navicula pusilla, N. mutica, Pinnularia microstauron, P. borealis, P. major, and Hantæschia amphioxys. However, it must be noted that some freshwater diatoms such as $N$. pusilla tolerate short-term rises in water salinity up to $20 \%$
(ZONG \& HoRTon 1997). Within this zone it is also evident that aerophilous taxa are becoming increasingly more important than in the lower altitudes of the salt marshes.

Dune slack deposits: Dune slack ecosystems are a special feature of Wadden Sea islands ( $\mathrm{PE}$ TERSEN 2000). In general, dune slack vegetation is distributed in valleys between the west-east stretching dune ridges. The valley bottoms are flooded mainly during winter due to influence from the groundwater table. As a result, peat deposits such as brown moss peat often accumulate. Unfortunately dune slack deposits are very rare, so that only one profile could demonstrate the succession pattern (profile Langeoog 3, Fig. 11).

In the basal layers of the profile, Diploneis interrupta is recorded as the dominant taxon whereas other species occur only in traces. As preserva- 
tion was very poor, a high degree of erosive selection has to be taken into account making this zone unsuitable for ecological interpretation. The subsequent zone is associated with terrestrialization or the beginning of peat accumulation. The diatom assemblage is initially dominated by Epithemia zebra var. porcellus, an epiphytic species which lives in shallow water and tolerates salinities up to $10 \%$. Littoral, brackish mesohalobous species such as Navicula peregrina are frequent and document a continuous but minor marine influence. However, oligohalobous and aerophilous species are the main component, e.g. Pinnularia div. spec., Cymbella aspera, Diploneis elliptica, and Navicula mutica. The deposit is a sedge peat consisting of numerous root fragments of undeterminable sedges. Following this zone there is a transition from sedge peat, with few brown moss remains, to a peat deposit mainly consisting of various moss species like Drepanocladus exannulatus, $D$. fuitans, and Calliergon cordifolium. This change is also reflected in the diatom assemblage. Pinnularia gibba, P. major and Navicula variostriata are increasing simultaneously, arguably suggesting oligohalobous conditions in a swampy environment. However, there is a short-term, weak increase in salinity, reflected by a sharp increase in numbers of Staurosira construens var. subsalina, a species which lives in shallow, moderately saline ponds. This change and the presence of the subsequent sand layer reflect the unfavourable environmental conditions leading to sand drift and severe inundations during the $17^{\text {th }}$ century, with the consequence that Langeoog was briefly inhabited during that period. The subsequent peat deposit, which possibly due to protection from sand dunes accumulated independently of severe marine influences, is again dominated by different Pinnularia species.

\section{Diatom groups and their application to the reconstruction of palaeoenvironments}

It is evident from the diatom diagrams that some assemblages occur repeatedly with the same succession pattern thereby characterizing a distinct palaeoenvironment. Therefore it is necessary to classify the recorded diatom assemblages into different ecological groups, which could be used for the determination of coastal palaeoenvironments in the southern North Sea (Table 2).

However, as there is no direct correlation between those groups and tidal levels, an indirect correlation has to be assumed. It is apparent that the habitat of every diatom is related to the hydrodynamic regime as well as the frequency of inundation. Correspondingly, species are differentiated according to their preference zones at sub-, inter- or supratidal levels (VOS \& DE WOLF 1988). The fragility of diatom frustules has often been used to estimate the importance of palaeotransport. Fragile species in the sequences indicate that they have lived at the site of deposition, and thus characterize the palaeoenvironment more effectively than the strongly silicified species. Generally, the influx of allochthonous species in low-energy environments can be ignored (Vos \& DE Wolf 1988). A suitable criterion for the importance of transport processes is the ratio between pelagic and littoral diatoms. A dominance of pelagic diatoms, which live mainly in the open sea, indicates that transport processes prevailed, whereas littoral species were deposited predominantly in or adjacent to their biotopes (SiMONSEN 1962). High ratios of marine pelagic species in limnic or oligohalobous environments verify a neighbouring shoreline and periodical marine influence. Therefore, it is important to differentiate between oligohalobous and polyhalobous pelagic diatoms. Salinity is probably the strongest environmental factor influencing the distribution of diatoms (Battarbee 1986). Consequently, diatoms are 
good indicators of long-term salinity changes in coastal areas caused by sea level fluctuations and marine influence.

All of the above criteria influence species composition and must therefore be considered in the reconstruction of palaeoenvironments in Holocene coastal deposits.

\section{Holocene diatom records as indicators of anthropogenic influences on coastal environments}

The recent coastal area of the southern North Sea has been formed by mainly natural process over the last 8000 years. Human activities, commencing around 2000 years BP with the building of settlements in the Roman Period and Early Middle Ages, had minor impact until the $11^{\text {th }}$ century when the building of dikes created a distinct interaction with hydrological and climatically derived physical processes. One of the consequences was a change in the hydrographic conditions of the inundated area, i.e. the restriction of the supratidal zone. Therefore, the assemblages and distribution patterns of diatoms were affected due to the versatility of habitats. In addition, the swamp-type characteristics of the supratidal zone also changed. The present-day salt marshes are well drained because of land reclamation and pasture. The modern supratidal zone is relatively close to tidal channels and experiences marine influence (Anderson \& Vos 1992). Diatom analyses in this study suggest the earlier salt marshes and the broad hinterland zone were increasingly swampy at this time. In all cores of the Pleistocene hinterland, the supratidal layers are characterized by larger numbers of diatoms with wider diversity (Dellwig 1999) than in present-day salt marshes. The species Diploneis interrupta reached a particularly high abundance in the salt marshes of the mainland as well as the East Friesian islands. This species is nowadays very rare in samples of anthropogenically-influenced environments (Dellwig et al. 1999).

Dikes also result in the reflection of waves which in former times lost their energy as they dispersed over a wide hinterland. These changes have contributed to a gradual increase of coarser sediments in the vicinity of the shoreline, whilst muddy sediments steadily become rarer (Flemming \& Davis 1994). Such a change of the sedimentary character of the tidal flats from muddy to coarser sediments has effected the diatom populations adapted to different grain-size compositions. Therefore the total number of epipelic species decreases, whilst the epipsammic diatoms increase. Changes in littoral diatom populations also have important implications for the food-web of shallow coastal ecosystems, in which large numbers of filter and deposit-feeders primarily feed on littoral diatom cells (DE JONGE 1992). The quantitative and qualitative reduction in diatoms will not only affect the tidal ecosystems, but also has implications for the North Sea in general because of the important role of the tidal ecosystems as nursery and breeding grounds for offshore communities (ANDERSON \& Vos 1992).

Although this study is limited to four cores on the mainland and five profiles of the East Friesian Islands, it illustrates the effectiveness of small scale facies analysis as a tool in coastal diatom palaeoecology. Knowledge of the changing palaeoenvironmental conditions is especially relevant for understanding anthropogenicallyinduced changes in the coastal areas. Fossil diatom assemblages are useful natural indicators providing palaeoecological data for the assessment of recent environmental changes.

\section{Acknowledgements}

The authors would like to thank Dr. J. Barckhausen and Dr. H. Streif (Niedersächsisches Landesamt für Bodenforschung, Hannover) 
for assistance with field work, the supply of sample material and lithological descriptions and for numerous fruitful discussions. Special acknowledgement is given to Prof. Dr. M. A. Geyh (Geowissenschaftliche Gemeinschaftsaufgaben, Hannover) for ${ }^{14} \mathrm{C}$-age determinations. The German Science Foundation (DFG) is recognized for the provision of financial support for these investigations (grants $\mathrm{Ge} 64 / 3$, STR 142/4, PO 313/17) which form part an interdisciplinary special research programme, "Biogeochemical and microfacies changes over the last 15,000 years - continental sediments as an expression of changing environmental conditions". We also like to thank Ann Bingham and Prof. Dr. M. O'Connell (University Galway, Ireland) for both comments and linguistic advice.

\section{References}

AdmiraAl, W. (1984): The ecology of estuarine sediment-inhabiting diatoms. - Phycological Research, 3: 269-322; London.

Anderson, J.N. \& Vos, P. (1992): Learning from the past: Diatoms as palaeoecology indicators of changes in marine environments. - Netherlands Journal of Aquatic Ecology, 26/1: 19-30; Dordrecht.

BARCKHAUSEN, J. (1969): Entstehung und Entwicklung der Insel Langeoog - Beiträge zur Quartärgeologie und Paläogeographie eines ostfriesischen Küstenabschnittes. - Oldenburger Jahrbuch, 68: 239-281; Oldenburg.

Battarbee, R.W. (1986): Diatom analysis. - In: Berglund, B.E. [Hrsg.]: Handbook of Holocene Palaeoecology and Palaeohydrology: 527-570; Chichester (Wiley).

Behre, K.-E., Dörjes, J. \& Irion, G. (1985): A dated Holocene sediment core from the bottom of the southern North Sea. - Eiszeitalter und Gegenwart, 35: 9-13; Stuttgart.

Benda, L. \& Streif H. 1971: Stratigraphie und Faziesentwicklung im Küstengebiet von Woltzeten in Ostfriesland. - Beihefte zum Geologischen Jahrbuch, 119: 1-59; Hannover.

Brockmann, C. (1928): Die Diatomeen im marinen Quartär von Holland. - Abhandlung der Senckenbergischen Naturforschenden Gesellschaft, 41: 73 S.; Frankfurt /M.

Brockmann, C. (1940): Diatomeen als Leitfossilien. - Westküste, II 2/3: 1-181; Kiel.

Cameron, T.D.J., Stoker, M.S. \& Long, D. (1987): The history of Quaternary sedimentation in the UK sector of the North Sea Basin. - Journal Geological Society London, 144: 43-58; London.

De Jonge, V.N. (1992): Physical processes and dynamics of microphytobenthos in the Ems estuary (The Netherlands). - Thesis, Rijksuniversiteit Groningen: 176 S.; Groningen.

Dellwig, O. (1999): Geochemistry of Holocene coastal deposits (NW Germany): Palaeoenvironmental reconstruction. - Dissertation, Universität Oldenburg: 297 S.; Oldenburg.

Dellwig, O., Gramberg, D., Vetter, D., Watermann, F., Barckhausen, J., Brumsack, H.-J., Gerdes, G., Rullkötter, J., Scholz-Böttcher, B. \& Streif, H. (1998): Geochemical and microfacial characterization of a Holocene depositional sequence of Northwest Germany. - Organic Geochemistry, 29/5-7: 1687-1699; Amsterdam.

Dellwig, O., Watermann, F., Brumsack, H.-J. \& Gerdes, G. (1999): High-resolution reconstruction of a Holocene coastal sequence (NW Germany) using inorganic geochemical data and diatom in-ventories.-Estuarine, Coastal and Shelf Science, 48: 617-633; Amsterdam.

Denys, L. (1994): Diatom assemblages along a former intertidal gradient: a palaeoecological study of a sub-boreal clay layer, western coastal plain, Belgium. - Netherland Jour- 
nal of Aquatic Ecology, 28/1: 85-96; Dordrecht.

Drebes, G. (1974): Marines Phytoplankton.186 S.; Stuttgart (Thieme).

Flemming, B.W. \& Davis, R.A. (1994): Holocene evolution, morphodynamics and sedimentology of the Spiekeroog barrier island system (Southern North Sea). - Senckenbergiana maritima, 24: 117-155; Frankfurt $/ \mathrm{M}$.

Freund, H. (2003): Die Dünen- und Salzwiesenvegetation auf Juist und deren Änderung als Indikator für die Entwicklung der Insel seit dem Frühen Mittelalter. -Probleme der Küstenforschung im südlichen Nordseegebiet28, 133-183; Oldenburg.

Freund, H. \& Streif, H. (1999): Natürliche Pegelmarken für Meeresspiegelschwankungen der letzten 2000 Jahre im Bereich der Insel Juist. - Petermanns Geographische Mitteilungen, 143: 34-45; Gotha.

Freund, H. \& Streif, H. (2000): Natural sealevel indicators recording the fluctuations of the mean high tide level in the southern North Sea. - Wadden Sea Newsletter, 2: 1618; Wilhelmshaven.

Freund, H., Petersen, J. \& Pott, R. (2003): Investigations on recent and subfossil saltmarsh vegetation of the East Frisian barrier islands in the southern North Sea (Germany). - Phytocoenologia, 13: 107-114; Berlin, Stuttgard.

Freund, H., Gerdes, G., Streif, H., Dellwig, O. \& Watermann, F. (2004): The indicator value of diatoms, pollen and botanical macro fossils for the reconstruction of sea-level fluctuations in the southern North Sea; Germany. - Quaternary International, 112/1: 71-87; Amsterdam.

Grimm, E. (1993): Tilia: a pollen program for analysis and display. - Springfield (Illinois State Museum).

Grohne, U. (1959): Die Bedeutung der Diatomeen zum Erkennen der subfossilen
Vegetation höherer Pflanzen in Marschablagerungen. - Zeitschrift der Deutschen Geologischen Gesellschaft, 11: 13-28; Stuttgart. Hartley, B.B., Barber, H.G. \& Carter, J.R. (1996): An atlas of British diatoms.- $601 \mathrm{~S}$; Bristol (Biopress Limited).

Hustedt, F. (1939): Die Diatomeenflora des Küstengebietes der Nordsee vom Dollart bis zur Elbmündung. - Abhandlungen des Naturwissenschaftlichen Vereins Bremen, 31: 572-677; Bremen.

Hustedt, F. (1957): Die Diatomeenflora des Flußsystems der Weser im Gebiet der Hansestadt Bremen. - Abhandlungen des Naturwissenschaftlichen Vereins Bremen, 34: 181-440; Bremen.

Jelgersma, S. (1979): Sea-level changes in the North Sea basin. - In: Oele, E. et al. [Hrsg.]: The Quaternary history of the North Sea. - Acta Univ. Ups. Symp. Univ. Ups. Annum Quingentesimum Celebrantis, 2: 233-248; Uppsala.

Juggins, S. (1992): Diatoms in the Thames estuary, England: ecology, palaeoecology and salinity transfer function. - Bibliotheca Diatomologica, 25: 1-216; Stuttgart.

Long, D., Laban, C., Streif, H., Cameron, T.D.J. \& SChuetTEnhelm, R.T.E. (1988): The sedimentary record of climatic variation in the Southern North Sea. - Philosophical Transactions of the Royal Society of London, B318: 523-537; London.

Ludwig, G., Müller, H. \& Streif, H. (1979):

Neuere Daten zum holozänen Meeresspiegelanstieg im Bereich der Deutschen Bucht.- Geologisches Jahrbuch, D32: 3-22; Hannover.

Menke, B. (1976): Befunde und Überlegungen zum nacheiszeitlichen Meeresspiegelanstieg. - Probleme der Küstenforschung im südlichen Nordseegebiet, 11: 145-161; Hildesheim.

Merkt, J. \& Streif, H. (1970): StechrohrBohrgeräte für limnische und marine 
Lockersedimente. - Geologisches Jahrbuch, 88: 137-148; Hannover.

Moore, J.W. \& Mcintire, C.D. (1977): Spatial and seasonal distribution of littoral diatoms in Yaquina estuary, Oregon. - Botanica Marina, 20: 99-109; Berlin, New York.

MülleR, W. (1977): Geologie. Exkursion Wesermarsch. - Mitteilungen der Deutschen Bodenkundlichen Gesellschaft Bremen, 24: 15-29; Bremen.

Palmer, A.J.M. \& Clague, J.J. (1986): Diatom assemblage analysis and sea level change. In: van de Plassche, O. [Hrsg.]: Sea-Level Research - A Manual for the Collection and Evaluation of Data: 457-487; Norwich (Geo Books).

Pankow, H. (1990): Ostsee-Algenflora. - 648 S.; Jena (Fischer).

Petersen, J. (2000): Die Dünentalvegetation der Wattenmeer-Inseln in der südlichen Nordsee - Eine pflanzensoziologische und ökologische Vergleichsuntersuchung unter Berücksichtigung von Nutzung und Naturschutz. - 205 S.; Husum (Husumer Druckund Verlagsges).

Petzelberger, B.E.M. (1997): Geologische Untersuchungen zur Landschaftsgeschichte des jüngeren Holozäns in der ehemaligen Crildumer Bucht im Wangerland, Ldkr. Friesland. - Probleme der Küstenforschung im südlichen Nordseegebiet, 24: 301-309; Oldenburg.

Scheer, K. (1953): Die Bedeutung von Phragmites communis Trin. für die Fragen der Küstenbildung. - Probleme der Küstenforschung im südlichen Nordseegebiet, 5: 1525; Hildesheim.

Schrader, H.J. (1973): Proposal for a standardized method of cleaning diatom-bearing deep-sea and land-exposed marine sediments. - Nova Hedwigia Beihefte, 45: 403409; Stuttgart.

Simonsen, R. (1962): Untersuchungen zur Systematik und Ökologie der Boden-dia- tomeen der westlichen Ostsee. 147 S.; Berlin (Akademie).

Stabell, B. (1982): The response of diatom floras during Late Quaternary shore line displacement in Southern and Western Norway. - Ph.D Thesis, University of Oslo.

Streif, H. (1990): Das ostfriesische Küsten-gebiet. Nordsee, Inseln, Watten und Marschen. Sammlung Geologischer Führer 57, 2. Aufl.: 376 S.; Stuttgart (Borntraeger).

UTERMÖHL, H. (1958): Zur Vervollkommnung der quantitativen Phytoplanktonmethodik.Mitteilungen der Internationalen Vereinigung der Limnologen, 9: 1-38; Stuttgard.

Vos, P.C. \& DE Wolf, H. (1988): Methodological aspects of palaeo-ecological diatom research in coastal areas of the Netherlands. - Geologie en Mijnbouw, 67: 31-40; Dordrecht.

Vos, P.C. \& de Wolf, H. (1993): Reconstruction of sedimentary environments in Holocene coastal deposits of southwest Netherlands; the Poostvliet boring, a case study of palaeoenvironmental diatom research.Hydrobiologica, 269/270: 297-306.

Vos; P.C. \& DE Wolf, H. (1994): Palaeoenvironmental research on diatoms in early and middle Holocene deposits in central north Holland (The Netherlands). - Netherlands Journal of Aquatic Ecology, 28(1): 97-115; Dordrecht.

ZAGWIJN, W.H. (1986): Nederland in het Holoceen. - Geologie van Nederland, Deel 1: 46 S.; Haarlem (Rijks Geol. Dienst).

Zong, Y. (1997): Mid- and late-Holocene sealevel changes in Roudsea Marsh, northwest England: a diatom biostratigraphical investigation. - The Holocene, 7/3: 311-323; London.

Zong, Y. \& Horton, B.P. (1999): Diatombased tidal-level transfer functions as an aid in reconstructing Quaternary history of sealevel movements in the UK. - Journal of Quaternary Science, 14/2: 153-167; Chichester. 